\title{
Helping the Released Guardian: Drug Combinations for Supporting the Anticancer Activity of HDM2 (MDM2) Antagonists
}

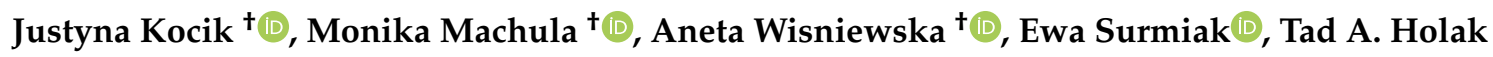 \\ and Lukasz Skalniak*(D) \\ Department of Organic Chemistry, Faculty of Chemistry, Jagiellonian University, Gronostajowa 2, \\ 30-387 Krakow, Poland \\ * Correspondence: lukasz.skalniak@uj.edu.pl; Tel.: +48-12-686-2435 \\ + These authors contributed equally to this work.
}

Received: 15 June 2019; Accepted: 16 July 2019; Published: 19 July 2019

\begin{abstract}
The protein p53, known as the "Guardian of the Genome", plays an important role in maintaining DNA integrity, providing protection against cancer-promoting mutations. Dysfunction of p53 is observed in almost every cancer, with $50 \%$ of cases bearing loss-of-function mutations/deletions in the TP53 gene. In the remaining 50\% of cases the overexpression of HDM2 (mouse double minute 2, human homolog) protein, which is a natural inhibitor of p53, is the most common way of keeping p53 inactive. Disruption of HDM2-p53 interaction with the use of HDM2 antagonists leads to the release of p53 and expression of its target genes, engaged in the induction of cell cycle arrest, DNA repair, senescence, and apoptosis. The induction of apoptosis, however, is restricted to only a handful of p53 ${ }^{\mathrm{wt}}$ cells, and, generally, cancer cells treated with HDM2 antagonists are not efficiently eliminated. For this reason, HDM2 antagonists were tested in combinations with multiple other therapeutics in a search for synergy that would enhance the cancer eradication. This manuscript aims at reviewing the recent progress in developing strategies of combined cancer treatment with the use of HDM2 antagonists.
\end{abstract}

Keywords: HDM2 antagonist; MDM2; p53; p21; synergy; combined cancer treatment; targeted therapy; chemotherapy; nutlin; RG7388; idasanutlin

\section{Introduction}

The protein p53 is a powerful regulator of cell fate. Together with a complex net of co-regulatory proteins it integrates multiple stress signals and translates them into several programs, such as cell cycle arrest, DNA-repair, senescence or apoptosis. One of the major roles fulfilled by p53 is the protection against early cancerogenic events by the induction of repair mechanisms in response to DNA mutations and by the controlled elimination of extensively damaged cells. For this reason, p53 protein has been called the "Guardian of the Genome". Not surprisingly, p53 is found functionally impaired in almost every cancer type. Therefore, since the discovery of its tumor-suppressive potential, the strategies of restoring its activity in cancer cells has become the Holy Grail of modern medicinal chemistry.

The progress in this field is best reflected by the development of small molecule antagonists of HDM2 (mouse double minute 2, human homolog) protein. HDM2 (in mouse known as Mdm2) is an E3 ubiquitin ligase that binds p53, blocks its trans-activating activity, governs its nuclear export and targets p53 to proteasomal degradation. While deactivation of p53 is a virtually obligatory step in cancer development [1], it is estimated that around $50 \%$ of cancers contain non-mutated (wild type) TP53 genes, which encode a functional p53 protein. In those cells, however, the activity of p53 is blocked 
predominantly by the overexpression of HDM2 protein, frequently achieved by the duplication of the HDM2 gene. In such cells, the administration of HDM2 antagonists results in forced dissociation of HDM2-p53 complexes, releasing p53 from HDM2 inhibition [2]. Such a forced p53 release results in the expression of a plethora of p53-regulated genes, presenting a transcriptome landscape similar, but not identical to that of genotoxic p53 activation [3]. However, the blockade of HDM2 protein leads only to partial activation of p53, and thus the outcome of such activation differs from the full p53 activation process observed in response to genotoxic stress.

\section{Limited Elimination of Cancer Cells by HDM2 Antagonists}

It has been well documented that the activation of p53 by HDM2 antagonists results in the inhibition of the growth of $\mathrm{p} 53^{\mathrm{wt}}$ cancer cells, both in vitro and in mouse xenograft models. However, while initially it has been expected that the activated p53 would lead to strong apoptosis in developed $\mathrm{p} 53^{\mathrm{wt}}$ cancers, with time, growing evidence pointed to serious limitations of this treatment strategy. First, it soon became clear that HDM2 antagonists induce apoptosis only in a limited subset of p53 ${ }^{\mathrm{wt}}$ cells $[4,5]$. In many additional p53 ${ }^{\mathrm{wt}}$ cell lines HDM2 antagonists induce cell cycle arrest, which is more like reversible quiescence rather than irreversible senescence [6]. Although the growth inhibition of cancer cells provides significant short-term therapeutic effects, the limited elimination of cancer cells gives them the time necessary to gain new genetic or epigenetic features that lead to the generation of secondary resistance. Such a phenomenon has been reported for almost every significant HDM2 antagonist [7-15]. Additionally, a recent study performed with the use of $113 \mathrm{p} 53^{\mathrm{wt}}$ cell lines showed that 70 of them are naturally resistant to such a treatment [16].

The limited apoptosis upon p53 release by HDM2 antagonists likely results from distinctive modes of p53 activity that leads either to cell cycle arrest and DNA repair or cell death. In the first mode, the activation of $\mathrm{p} 53$ results in the induction of the expression of proteins engaged in cell cycle arrest, such as p21 [17], and the proteins that assure negative feedback loops required for the generation of p53 activation pulses, such as HDM2 and Wip-1 (wild-type p53-induced phosphatase 1) [18,19]. Cell cycle arrest is also partially related to the transcriptional downregulation of genes related to the cell cycle. In this process, DREAM (dimerization partner, RB-like, E2F and multi-vulval class B) protein complex acts as a transcriptional repressor by binding to E2F and CHR (cell cycle genes homology region) elements. This p53-p21-DREAM pathway regulates the expression of over 250 genes, most of which are involved in the cell cycle. Moreover, DREAM complex controls genes responsible for DNA repair, telomere maintenance and chromosomal instability [20]. Given the nature of p53 in this mode, it is called p53 ARRESTER and is characterized by the phosphorylation at Ser15 and Ser20 residues [21]. The second mode requires additional phosphorylation of p53 at the Ser46 residue, resulting in a so-called p53 KILLER [22]. This version of p53 results in the induction of apoptosis at least partially by the activation of a positive p53-PTEN (phosphatase and tensin homolog deleted on chromosome ten)-Akt-HDM2 loop [23] and induction of the expression of pro-apoptotic Bax protein [24]. Such a complex but fine regulation of p53 activity provides a tunable, coordinated response to DNA damage, first giving the cell a chance to fix the damage, but eliminating the cell if the repair machinery should have failed.

Since the transition from $\mathrm{p} 53_{\text {ARRESTER }}$ to $\mathrm{p} 53_{\text {KILLER }}$ requires the accumulation of HIPK2 kinase (homeodomain-interacting protein kinase 2) in response to severe DNA damage [25] and normally occurs after several cycles of the induction of p53 ARRESTER protein [22,26,27], it is not easily achieved by a rough p53 release evoked by HDM2 antagonists. Additionally, the forced release of p53 by HDM2 antagonists seem to be devoid of the proper cellular context and other mechanistic features, that is required for enabling proapoptotic functioning of p53 [28]. Moreover, it was proposed that it is the pulse of p53 activation in the G2 phase of the cell cycle which result in irreversible senescence of DNA-damaged cell, while HDM2 antagonists arrest the cells predominantly in the G1 phase, where the cells remain the potency of re-entering mitosis [29]. For these reasons, HDM2 antagonists require the use of supporting agents that would provide synergistic therapeutic effects. In fact, besides a substantial 
work on the optimization of lead molecules [30,31], much effort has been done in the last ten years in the field of the development of combined treatment strategies, that would incorporate HDM2 antagonists into successful anti-cancer treatment regimes. The successful combinations attempt to support HDM2 antagonists most often by inducing natural DNA damage signaling (achieved with DNA-damaging chemical agents or irradiation), blocking pro-survival or p53-inhibitory circuits (inhibitors of signaling kinases, such as Akt, (protein kinase B) or phosphatases, such as Wip-1), or increasing proapoptotic signaling in cancer cells (inhibitors of antiapoptotic proteins, TRAIL (TNF-related apoptosis-inducing ligand) agonists etc.) (Figure 1).

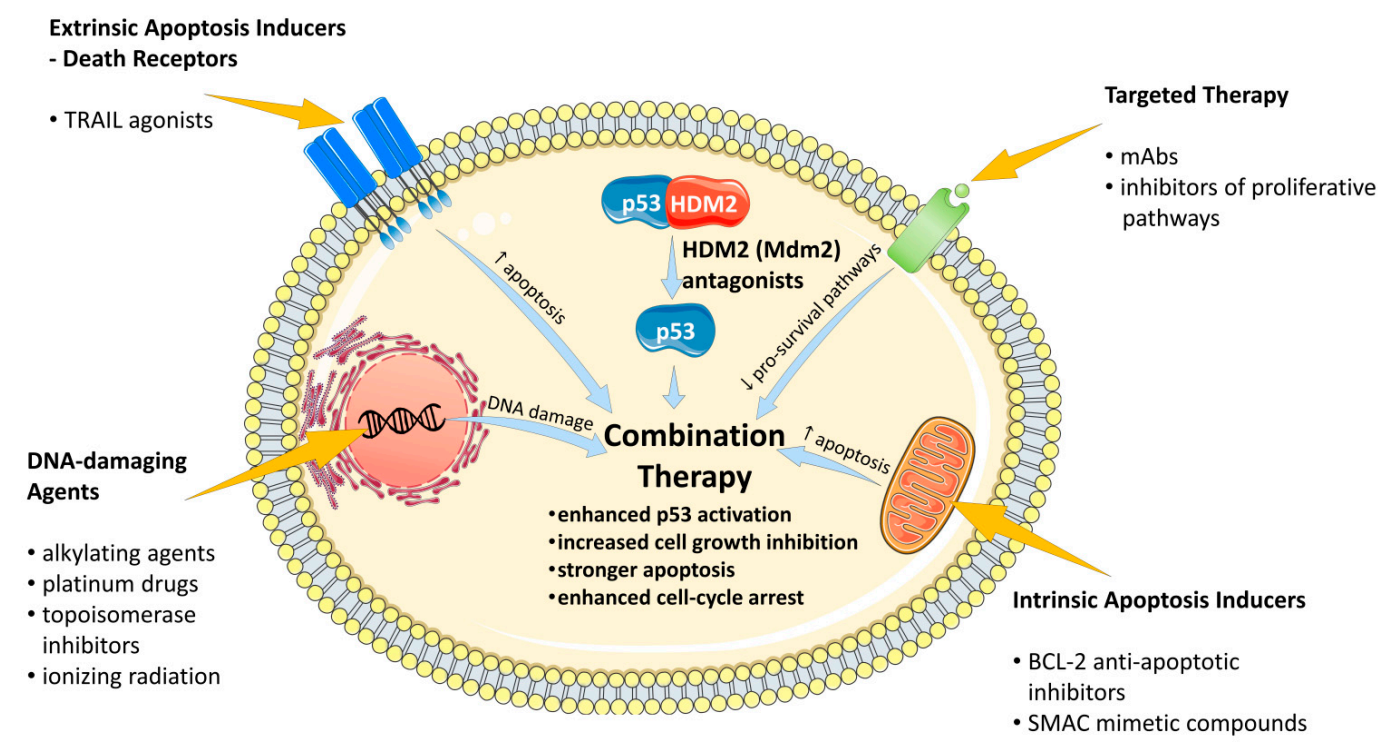

Figure 1. The outline of the main strategies of supporting the action of HDM2 (mouse double minute2, Mdm2, human homolog) antagonists in the recent experimental combination therapies.

In this manuscript, we first shortly outline the most important and most potent HDM2 antagonists, and then review the potential positive therapeutic interactions of these molecules with well-established anti-cancer agents, grouped by the general mechanism of action of these agents (see also Table 1). 
Table 1. The summary of combination therapies of HDM2 antagonists.

\begin{tabular}{|c|c|c|c|c|c|c|}
\hline \multirow[b]{2}{*}{ Mode of Action } & \multicolumn{2}{|c|}{ Combination } & \multirow[b]{2}{*}{ In Vitro Studies } & \multirow[b]{2}{*}{ In Vivo Studies } & \multirow[b]{2}{*}{ Clinical Trials } & \multirow[b]{2}{*}{ References } \\
\hline & $\begin{array}{c}\text { Therapeutic } \\
\text { Agent }\end{array}$ & $\begin{array}{c}\text { HDM2 } \\
\text { Antagonist }\end{array}$ & & & & \\
\hline \multirow{19}{*}{ 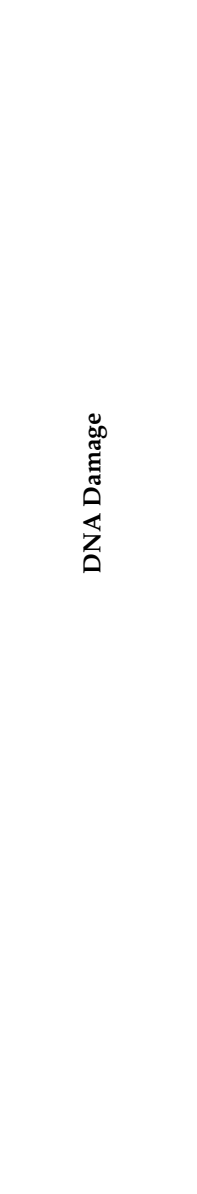 } & 5-azacitadine & DS-3032b & - & - & AML or MDS, Phase 1 & NCT02319369 \\
\hline & 5-fluorouracil & CGM097 & neuroendocrine tumor cell lines & - & - & [32] \\
\hline & acadesine & nutlin-3a & CLL & - & - & [33] \\
\hline & busulfan & idasanutlin & neuroblastoma & - & - & [34] \\
\hline & \multirow{3}{*}{ carboplatin } & AMG-232 & different tumor cell lines & $\begin{array}{l}\text { osteosarcoma, colorectal } \\
\text { carcinoma, melanoma, NSCLC } \\
\text { xenograft mouse models }\end{array}$ & - & [35] \\
\hline & & APG-115 & - & - & $\begin{array}{l}\text { salivary gland carcinoma, } \\
\text { Phase } 1 / 2\end{array}$ & NCT03781986 \\
\hline & & nutlin-3a & breast cancer & $\begin{array}{c}\text { breast cancer xenograft mouse } \\
\text { models }\end{array}$ & - & [36] \\
\hline & \multirow{5}{*}{ cisplatin } & AMG-232 & different tumor cell lines & $\begin{array}{l}\text { osteosarcoma, colorectal } \\
\text { carcinoma, melanoma, NSCLC } \\
\text { xenograft mouse models }\end{array}$ & - & [35] \\
\hline & & idasanutlin & ovarian cancer, neuroblastoma & - & - & {$[34,37]$} \\
\hline & & MI-319 & pancreatic cancer & - & - & [38] \\
\hline & & nutlin-3 & $\begin{array}{c}\text { nasopharyngeal carcinoma, } \\
\text { adenocarcinoma, ovarian cancer }\end{array}$ & - & - & {$[37,39-41]$} \\
\hline & & nutlin-3a & $\begin{array}{c}\text { liposarcoma, RMS, } \\
\text { neuroblastoma, osteosarcoma }\end{array}$ & - & - & {$[42,43]$} \\
\hline & chlorambucil & nutlin-3a & CLL & - & - & [33] \\
\hline & СРT-11 & AMG-232 & different tumor cell lines & $\begin{array}{c}\text { osteosarcoma, colorectal } \\
\text { carcinoma, melanoma, NSCLC } \\
\text { xenograft mouse models }\end{array}$ & - & [35] \\
\hline & \multirow{5}{*}{ cytarabine } & ALRN-6924 & - & - & AML and AMS, Phase 1 & NCT02909972 \\
\hline & & CGM097 & AML & - & - & [44] \\
\hline & & HDM-201 & AML & - & AML, Phase 1/2 & $\begin{array}{c}{[44]} \\
\text { NCT03760445 }\end{array}$ \\
\hline & & idasanutlin & - & - & AML, Phase 1/2, Phase 3 & $\begin{array}{l}\text { NCT03850535 } \\
\text { NCT02545283 }\end{array}$ \\
\hline & & RG7112 & - & - & AML, Phase 1 & NCT01635296 \\
\hline
\end{tabular}


Table 1. Cont

\begin{tabular}{|c|c|c|c|c|c|c|}
\hline \multirow{22}{*}{ 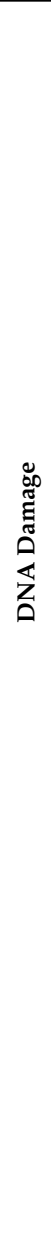 } & \multirow{2}{*}{ daunorubicin } & HDM-201 & - & - & AML, Phase 1/2 & NCT03760445 \\
\hline & & idasanutlin & - & - & AML, Phase $1 / 2$ & NCT03850535 \\
\hline & decitabine & AMG-232 & - & - & AML, Phase 1 & NCT03041688 \\
\hline & \multirow{3}{*}{ doxorubicin } & AMG-232 & different tumor cell lines & $\begin{array}{l}\text { osteosarcoma, colorectal } \\
\text { carcinoma, melanoma, NSCLC } \\
\text { xenograft mouse models }\end{array}$ & - & [35] \\
\hline & & idasanutlin & neuroblastoma & - & - & [34] \\
\hline & & nutlin-3a & $\begin{array}{l}\text { DLBCL, CLL, PDAC, } \\
\text { liposarcoma, RMS and } \\
\text { osteosarcoma }\end{array}$ & DLBCL xenograft mouse models & - & {$[33,42,45,46]$} \\
\hline & \multirow{3}{*}{ etoposide } & MI-219 & lung cancer & - & - & [47] \\
\hline & & nutlin-3 & ovarian cancer & - & - & [41] \\
\hline & & nutlin-3a & PDAC, neuroblastoma & - & - & {$[43,46]$} \\
\hline & fludarabine & nutlin-3a & CLL & - & - & {$[33,48]$} \\
\hline & \multirow{2}{*}{ gemcitabine } & MI-63 & MCL & - & - & [49] \\
\hline & & nutlin-3a & PDAC & - & - & [46] \\
\hline & \multirow{2}{*}{ idarubicin } & CGM097 & \multirow{2}{*}{ AML } & \multirow[t]{2}{*}{-} & \multirow[t]{2}{*}{ - } & \multirow{2}{*}{ [44] } \\
\hline & & HDM-201 & & & & \\
\hline & \multirow{3}{*}{$\begin{array}{l}\text { ionizing } \\
\text { radiation (IR) }\end{array}$} & AMG-232 & - & $\begin{array}{l}\text { adenoid cystic carcinoma } \\
\text { xenograft mouse models }\end{array}$ & $\begin{array}{l}\text { glioblastoma, Phase 1, } \\
\text { soft tissue sarcoma, } \\
\text { Phase } 1\end{array}$ & $\begin{array}{c}{[50]} \\
\text { NCT03107780 } \\
\text { NCT03217266 }\end{array}$ \\
\hline & & RG7388 & - & RMS xenograft mouse models & - & [51] \\
\hline & & nutlin-3 & $\begin{array}{c}\text { LSCC, } \\
\text { glioblastoma }\end{array}$ & - & - & {$[52,53]$} \\
\hline & oxaliplatin & MI-219 & $\begin{array}{c}\text { PDAC, colon } \\
\text { and breast cancer }\end{array}$ & - & - & [54] \\
\hline & \multirow{3}{*}{ temozolomide } & CGM097 & neuroendocrine tumor cell lines & - & - & [32] \\
\hline & & idasanutlin & neuroblastoma & - & - & [34] \\
\hline & & RG7775 & neuroblastoma & $\begin{array}{l}\text { neuroblastoma mouse xenograft } \\
\text { models }\end{array}$ & - & [55] \\
\hline & topotecan & idasanutlin & neuroblastoma & - & - & [34] \\
\hline
\end{tabular}


Table 1. Cont

\begin{tabular}{|c|c|c|c|c|c|c|c|}
\hline & & trabectedin & RG7112 & $\begin{array}{c}\text { fibrosarcoma } \\
\text { and liposarcoma }\end{array}$ & - & - & [56] \\
\hline & \multirow{7}{*}{ 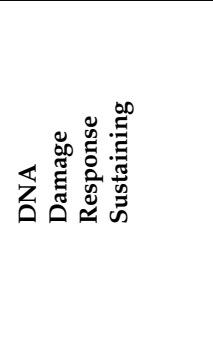 } & \multirow{5}{*}{ GSK2830371 } & ATSP-7041 & Ewing sarcoma & - & - & [57] \\
\hline & & & HDM-201 & \multirow{3}{*}{ human melanoma } & \multirow{3}{*}{ - } & \multirow{3}{*}{ - } & \multirow{3}{*}{ [15] } \\
\hline & & & idasanutlin, & & & & \\
\hline & & & nutlin-3, & & & & \\
\hline & & & nutlin-3a & $\begin{array}{c}\text { osteosarcoma, breast, colon } \\
\text { adenocarcinoma }\end{array}$ & - & - & {$[58]$} \\
\hline & & \multirow{2}{*}{ rucaparib } & idasanutlin & \multirow{2}{*}{ ovarian cancer } & \multirow{2}{*}{ - } & \multirow{2}{*}{ - } & \multirow{2}{*}{ [59] } \\
\hline & & & nutlin-3 & & & & \\
\hline \multirow{13}{*}{ 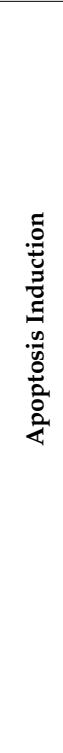 } & \multirow{3}{*}{ 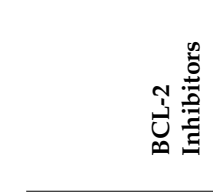 } & ABT-263 & SAR405838 & ALL and AML & $\begin{array}{l}\text { ALL and AML xenograft mouse } \\
\text { models }\end{array}$ & - & [10] \\
\hline & & \multirow[t]{2}{*}{ ABT-737 } & MI-63 & multiple myeloma & $\begin{array}{l}\text { multiple myeloma xenograft } \\
\text { mouse models }\end{array}$ & - & [60-62] \\
\hline & & & nutlin-3 & $\mathrm{AML}, \mathrm{CML}$ & - & - & {$[60,61]$} \\
\hline & \multirow{3}{*}{ 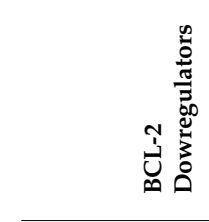 } & oridonin & nutlin-3 & osteosarcoma & - & - & [63] \\
\hline & & venetoclax & idasanutlin & AML, neuroblastoma & $\begin{array}{l}\text { AML, neuroblastoma xenograft } \\
\text { mouse models }\end{array}$ & $\begin{array}{l}\text { AML patients, } \\
\text { Phase } 1 \mathrm{~b} / 2\end{array}$ & $\begin{array}{c}{[64,65]} \\
\text { NCT02670044 }\end{array}$ \\
\hline & & $\begin{array}{c}\text { venetoclax }+ \\
\text { obinutuzumab } \\
\text { or rituximab }\end{array}$ & idasanutlin & - & - & follicular lymphoma and DLBCL & NCT03135262 \\
\hline & \multirow{3}{*}{$\sum_{\infty}$} & $1396-11$ & \multirow{2}{*}{ nutlin-3a } & \multirow{2}{*}{ AML } & \multirow[t]{2}{*}{-} & \multirow[t]{2}{*}{-} & \multirow[t]{2}{*}{ [66] } \\
\hline & & ABT-10 & & & & & \\
\hline & & SM-164 & MI-219 & lung cancer & - & - & [47] \\
\hline & \multirow{4}{*}{ 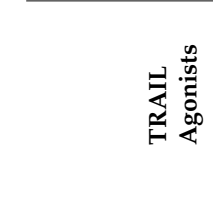 } & D269H/E195R & nutlin-3 & NSCLC, colon, ovarian cancer & - & - & [67] \\
\hline & & \multirow{3}{*}{ rhTRAIL } & nutlin-3 & NSCLC, colon, ovarian cancer & - & - & [67] \\
\hline & & & nutlin-3a & MPM & - & - & [68] \\
\hline & & & RG7112 & - & $\begin{array}{l}\text { MPM xenograft } \\
\text { mouse models }\end{array}$ & - & [68] \\
\hline
\end{tabular}


Table 1. Cont.

\begin{tabular}{|c|c|c|c|c|c|c|c|}
\hline \multirow{25}{*}{ 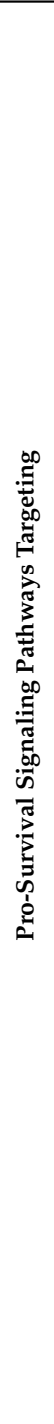 } & & \multirow{2}{*}{ alpelisib } & CGM097 & \multirow{2}{*}{ AML } & \multirow[t]{2}{*}{-} & \multirow[t]{2}{*}{-} & \multirow[t]{2}{*}{ [44] } \\
\hline & & & HDM-201 & & & & \\
\hline & & \multirow{2}{*}{ buparlisib } & CGM097 & \multirow{2}{*}{ AML } & \multirow[t]{2}{*}{-} & \multirow[t]{2}{*}{-} & \multirow{2}{*}[44]{} \\
\hline & & & HDM-201 & & & & \\
\hline & & ceritinib & CGM097 & neuroblastoma & $\begin{array}{l}\text { neuroblastoma xenograft mouse } \\
\text { models }\end{array}$ & - & {$[69]$} \\
\hline & & \multirow{2}{*}{ dasatinib } & nutlin-3 & B-CLL & - & - & [70] \\
\hline & & & nutlin-3a & ALL & - & - & [71] \\
\hline & & \multirow{2}{*}{ gilterinib } & CGM097 & \multirow{2}{*}{ AML } & \multirow[t]{2}{*}{-} & \multirow[t]{2}{*}{-} & \multirow{2}{*}[44]{} \\
\hline & & & HDM-201 & & & & \\
\hline & 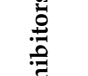 & ibrutinib & nutlin-3 & CLL & $\begin{array}{l}\text { CLL xenograft } \\
\text { mouse models }\end{array}$ & - & {$[72]$} \\
\hline & 志 & imatinib & nutlin-3a & ALL & - & - & [71] \\
\hline & 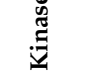 & \multirow{2}{*}{ midostaurin } & CGM097 & AML & $\begin{array}{l}\text { AML xenograft } \\
\text { mouse models }\end{array}$ & - & {$[44,73]$} \\
\hline & 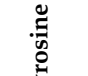 & & HDM-201 & AML & - & $\begin{array}{c}\text { AML, } \\
\text { Phase } 1 / 2\end{array}$ & $\begin{array}{c}{[44]} \\
\text { NCT03760445 }\end{array}$ \\
\hline & & \multirow{2}{*}{ nilotinib } & nutlin-3 & AML, CML & - & - & {$[60,61]$} \\
\hline & & & nutlin-3a & ALL & - & - & [71] \\
\hline & & pictilisib & $\begin{array}{c}\text { CGM097 } \\
\text { HDM-201 }\end{array}$ & AML & - & - & {$[44]$} \\
\hline & & \multirow{2}{*}{ quizartinib } & CGM097 & AML & $\begin{array}{l}\text { AML xenograft } \\
\text { mouse models }\end{array}$ & - & {$[73]$} \\
\hline & & & DS-3032b & - & - & $\begin{array}{l}\text { AML, } \\
\text { Phase } 1\end{array}$ & NCT03552029 \\
\hline & & ruxolitinib & KRT232 & - & - & $\begin{array}{c}\text { PV, } \\
\text { Phase 2a/2b }\end{array}$ & NCT03669965 \\
\hline & & sorafenib & nutlin-3 & AML, RCC & - & - & {$[74,75]$} \\
\hline & \multirow{5}{*}{ 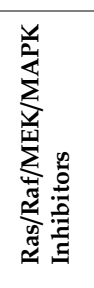 } & \multirow{2}{*}{ AZD6244 } & CGM097 & AML & - & - & [76] \\
\hline & & & nutlin-3a & AML & - & - & [77] \\
\hline & & dabrafenib & AMG-232 & different human cancer cell lines & $\begin{array}{c}\text { colorectal cancer xenograft mouse } \\
\text { models }\end{array}$ & $\begin{array}{l}\text { melanoma, } \\
\text { Phase } 1\end{array}$ & $\begin{array}{c}\text { NCT02110355 } \\
{[78,79]}\end{array}$ \\
\hline & & LGX818 & CGM097 & melanoma & melanoma mouse models & - & {$[80]$} \\
\hline & & PD0325901 & AMG-232 & different human cancer cell lines & $\begin{array}{c}\text { colorectal cancer xenograft mouse } \\
\text { models }\end{array}$ & - & [79] \\
\hline
\end{tabular}


Table 1. Cont

\begin{tabular}{|c|c|c|c|c|c|c|c|}
\hline \multirow{20}{*}{ 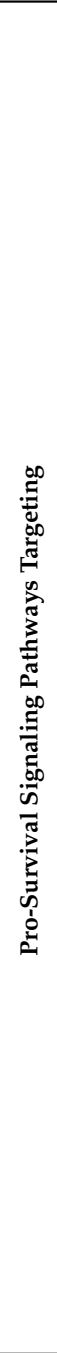 } & \multirow{5}{*}{ 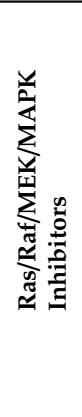 } & pimasertib & SAR405838 & - & - & different tumor types, Phase 1 & $\begin{array}{c}\text { NCT01985191 } \\
{[81]}\end{array}$ \\
\hline & & \multirow{3}{*}{ trametinib } & AMG-232 & different human cancer cell lines & $\begin{array}{l}\text { colorectal cancer xenograft mouse } \\
\text { models }\end{array}$ & $\begin{array}{l}\text { AML, Phase } 1 \mathrm{~b} \\
\text { melanoma, Phase } 1\end{array}$ & $\begin{array}{c}{[78,79]} \\
\text { NCT02016729 } \\
\text { NCT02110355 }\end{array}$ \\
\hline & & & HDM-201 & cutaneous melanoma & - & $\begin{array}{l}\text { colorectal carcinoma, } \\
\text { Phase } 1\end{array}$ & $\begin{array}{c}{[82]} \\
\text { NCT03714958 }\end{array}$ \\
\hline & & & $\begin{array}{c}\text { idasanutlin } \\
\text { nutlin-3 }\end{array}$ & cutaneous melanoma & - & - & [82] \\
\hline & & vemurafenib & AMG-232 & different human cancer cell lines & $\begin{array}{c}\text { colorectal cancer xenograft mouse } \\
\text { models }\end{array}$ & - & [79] \\
\hline & \multirow{10}{*}{ 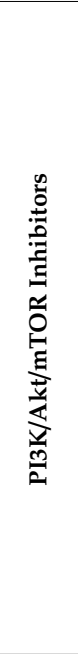 } & AMG511 & AMG-232 & different human cancer cell lines & $\begin{array}{l}\text { colorectal cancer xenograft mouse } \\
\text { models }\end{array}$ & - & [79] \\
\hline & & AZD8055 & AMG-232 & different human cancer cell lines & $\begin{array}{c}\text { colorectal cancer xenograft mouse } \\
\text { models }\end{array}$ & - & [79] \\
\hline & & \multirow{2}{*}{ BEZ235 } & AMG-232 & different human cancer cell lines & $\begin{array}{l}\text { colorectal cancer xenograft mouse } \\
\text { models }\end{array}$ & - & [79] \\
\hline & & & Idasanutlin & liposarcoma & $\begin{array}{l}\text { liposarcoma xenograft mouse } \\
\text { models }\end{array}$ & - & [83] \\
\hline & & everolimus & CGM097 & neuroendocrine tumor & - & - & {$[32]$} \\
\hline & & GDC-0941 & AMG-232 & different human cancer cell lines & $\begin{array}{c}\text { colorectal cancer xenograft mouse } \\
\text { models }\end{array}$ & - & [79] \\
\hline & & Ly294002 & nutlin-3 & ALL & - & - & [84] \\
\hline & & MK-2206 & AMG-232 & different human cancer cell lines & $\begin{array}{l}\text { colorectal cancer xenograft mouse } \\
\text { models }\end{array}$ & - & [79] \\
\hline & & PI103 & nutlin-3 & AML & - & - & [85] \\
\hline & & perifosine & nutlin-3 & $\begin{array}{l}\text { AML, } \\
\text { B-CLL }\end{array}$ & - & - & [86] \\
\hline & \multirow{5}{*}{ 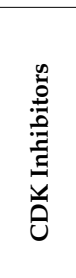 } & abemaciclib & nutlin-3a & liposarcoma & - & - & [87] \\
\hline & & \multirow[t]{2}{*}{ palbociclib } & idasanutlin & liposarcoma & $\begin{array}{l}\text { liposarcoma xenograft mouse } \\
\text { models }\end{array}$ & - & [88] \\
\hline & & & nutlin-3a & liposarcoma & - & - & [87] \\
\hline & & \multirow[t]{2}{*}{ ribociclib } & HDM-201 & - & - & $\begin{array}{l}\text { liposarcomas, } \\
\text { Phase } 1 b / 2\end{array}$ & NCT02343172 \\
\hline & & & nutlin-3a & liposarcoma & - & - & [87] \\
\hline
\end{tabular}


Table 1. Cont.

\begin{tabular}{|c|c|c|c|c|c|c|c|}
\hline & & \multirow[b]{2}{*}{ seliciclib } & nutlin-3 & neuroblasto-ma & - & - & [89] \\
\hline & & & nutlin-3a & $\begin{array}{l}\text { melanoma, breast, } \\
\text { colon adenocarci-noma, } \\
\text { liver carcinoma }\end{array}$ & - & - & [90] \\
\hline & \multirow{2}{*}{ 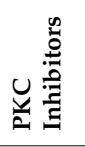 } & LXS196 & HDM-201 & - & - & $\begin{array}{c}\text { metastatic uveal melanoma, } \\
\text { Phase } 1\end{array}$ & NCT02601378 \\
\hline & & sotrastaurin & CGM097 & uveal melanoma & $\begin{array}{l}\text { uveal melanoma xenograft mouse } \\
\text { models }\end{array}$ & - & [91] \\
\hline \multirow{8}{*}{ 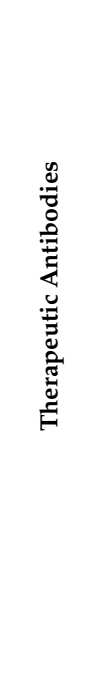 } & $\overline{\tilde{\Xi}}$ & atezolizumab & idasanutlin & - & - & $\begin{array}{c}\text { metastatic ER + breast cancer, } \\
\text { Phase } 1 b / 2\end{array}$ & NCT03566485 \\
\hline & 官定 & pembrolizumab & APG-115 & - & - & $\begin{array}{l}\text { unresectable or metastatic } \\
\text { melanoma, advanced solid } \\
\text { tumors, Phase } 1 \mathrm{~b} / 2\end{array}$ & NCT03611868 \\
\hline & 焉焉 & spartalizumab & HDM-201 & - & - & $\begin{array}{c}\text { colorectal cancer, RCC } \\
\text { Phase } 1\end{array}$ & NCT02890069 \\
\hline & & & nutlin-3 & CLL & - & - & [92] \\
\hline & 己ิ & obinutuzumab & idasanutlin & MCL, DLBCL & $\begin{array}{l}\text { MCL, DLBCL mouse xenograft } \\
\text { models }\end{array}$ & $\begin{array}{l}\text { FL, DLBCL, } \\
\text { Phase } 1 \mathrm{~b} / 2\end{array}$ & $\begin{array}{c}{[93]} \\
\text { NCT02624986 } \\
\text { NCT03135262 }\end{array}$ \\
\hline & $\stackrel{\underline{I}}{\underline{I}}$ & & nutlin-3 & CLL & - & - & [92] \\
\hline & & rituximab & idasanutlin & MCL, DLBCL & $\begin{array}{l}\text { MCL, DLBCL mouse xenograft } \\
\text { models }\end{array}$ & $\begin{array}{l}\text { FL, DLBCL, } \\
\text { Phase } 1 b / 2\end{array}$ & $\begin{array}{c}{[93]} \\
\text { NCT02624986 } \\
\text { NCT03135262 } \\
\end{array}$ \\
\hline & & drozitumab & nutlin-3a & $\begin{array}{l}\text { osteosarcoma, } \\
\text { Ewing's sarcoma }\end{array}$ & - & - & [94] \\
\hline & & bortezomib & nutlin-3 & $\begin{array}{l}\text { MCL, myeloma, breast, prostate, } \\
\text { thyroid, colon cancer }\end{array}$ & - & - & [95-97] \\
\hline & & carfilzomib & AMG-232 & - & - & multiple myeloma, Phase 1 & NCT03031730 \\
\hline 岕 & 总象 & $\begin{array}{l}\text { ixazomib } \\
\text { citrate }\end{array}$ & idasanutlin & - & - & multiple myeloma, Phase 1/2 & NCT0263305 \\
\hline 总 & & MG-132 & nutlin-3 & schwannoma & $\begin{array}{l}\text { schwannoma xenograft mouse } \\
\text { models }\end{array}$ & - & [98] \\
\hline & & SAHA & idasanutlin & AML & - & - & [99] \\
\hline & 突䓂 & VPA & nutlin-3 & AML & $\begin{array}{l}\text { AML xenograft } \\
\text { mouse models }\end{array}$ & - & {$[100]$} \\
\hline
\end{tabular}


Table 1. Cont.

\begin{tabular}{|c|c|c|c|c|c|c|c|}
\hline \multirow{13}{*}{ 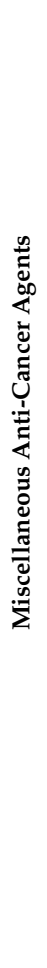 } & \multirow{2}{*}{ 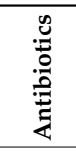 } & \multirow{2}{*}{ actinomycin D } & \multirow{2}{*}{ nutlin-3 } & RMS & \multirow{2}{*}{-} & \multirow{2}{*}{-} & [101] \\
\hline & & & & $\begin{array}{l}\text { different cancer } \\
\text { cell lines }\end{array}$ & & & [102] \\
\hline & \multirow{2}{*}{ : } & zinc & MI-219 & colon and breast cancer & - & - & [38] \\
\hline & & $\mathrm{ZMC1}$ & nutlin & $\begin{array}{l}\text { ovarian, lung, nasopharyngeal } \\
\text { cancer }\end{array}$ & ovarian xenograft mouse models & - & [103] \\
\hline & 营 & geldanamycin & nutlin-3 & AML & - & - & [104] \\
\hline & 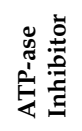 & archazolid & nutlin-3a & $\begin{array}{l}\text { liver, cervical, breast cancer, } \\
\text { glioblastoma }\end{array}$ & glioblastoma xenograft models & - & [105] \\
\hline & 总 & paclitaxel & ALRN-6924 & - & - & $\begin{array}{c}\text { advanced, metastatic, or } \\
\text { unresectable solid tumors, } \\
\text { Phase } 1\end{array}$ & NCT03725436 \\
\hline & 串泀 & vincristine & nutlin-3 & RMS & - & - & [101] \\
\hline & & & RG7112 & leukemia cell lines & $\begin{array}{l}\text { MLL-ALL xenograft mouse } \\
\text { models }\end{array}$ & - & [106] \\
\hline & & metformin & nutlin-3a & malignant mesothelioma & - & - & [107] \\
\hline & 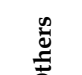 & methotrexate & nutlin-3a & $\begin{array}{l}\text { liposarcoma, RMS and } \\
\text { osteosarcoma }\end{array}$ & - & - & [42] \\
\hline & & tanshinone IIA & nutlin-3 & AML & - & - & [108] \\
\hline & & P5091 & ATSP-7041 & Ewing sarcoma & - & - & [57] \\
\hline
\end{tabular}

ALL—acute lymphocytic leukemia, AML—acute myeloid leukemia, AMS—advanced myelodysplastic syndrome, CLL—chronic lymphoblastic leukemia, CML—chronic myeloid leukemia,

DLBCL—diffuse large B-cell lymphoma, FL—follicular lymphoma, LSCC—laryngeal carcinoma, MCL — mantle cell lymphoma, MDS—myelodysplastic syndrome, MLL-mixed lineage leukemia, MPM—-malignant pleural mesothelioma, NSCLC—non- small cell lung carcinoma, PDAC—pancreatic ductal adenocarcinoma, PV—polycythemia vera, RCC—renal cell carcinoma, RMS-rhabdomyosarcoma. 


\section{The Most Significant Representatives of HDM2 Antagonists}

Since the discovery of the first potent small-molecular inhibitors of HDM2-p53 interactions, numerous chemical scaffolds have been published and tested [31,109]. Several promising compounds are currently being tested in cancer-related clinical trials $[30,110]$. In general, these formulas are designed using the three-finger pharmacophore model in which three substituents are selected to mimic natural interaction between $\mathrm{p} 53$ and HDM2 proteins based on Phe19, Trp23 and Leu27 amino acids of the p53 side chain (Figure 2) [111,112].
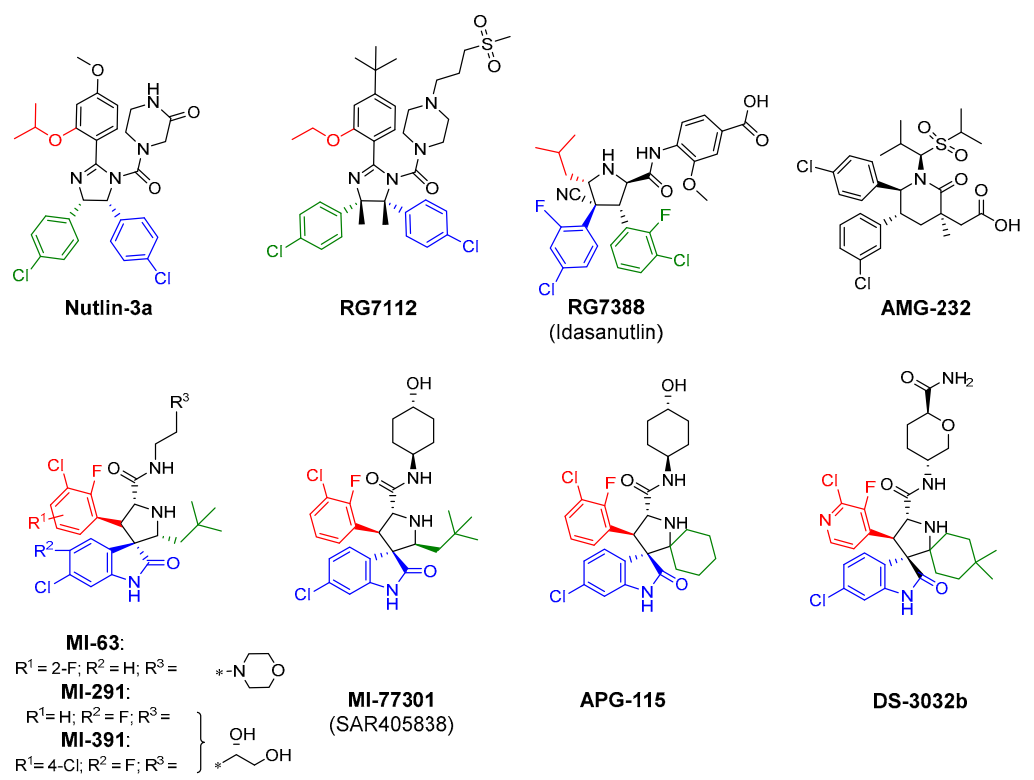

APG-115

DS-3032b
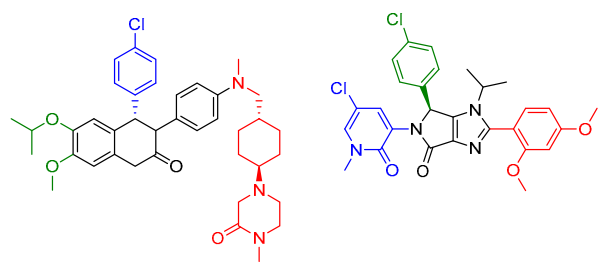

NVP-CGM097

$$
\underset{\text { (SDM-201 }}{\text { Siremadlin) }}
$$

(Siremadlin)

Figure 2. Structures of the potent HDM2 antagonists used in combination therapies. Binding of the compounds with protein HDM2 subpockets based on crystal structure or predicted is color labeled: Trp23-blue; Phe19-red; Leu26-green.

One of the earliest HDM2 antagonists, discovered by Hoffman-La Roche (Basel, Switzerland) in the early 21st century, are called the nutlins and are built around the cis-imidazoline core [113]. Following the initial discovery of nutlin-3a in 2004, the more potent representative of this family, RG7112, was developed [114]. The co-crystal structures with HDM2 (for example see PDB ID: 4 HG7, 4JRG) showed that the two cis-oriented phenyl rings occupy Leu27 and Trp23 pockets, whereas the alkoxy group (isopropoxy in case of nutlin-3a and ethoxy in RG7112) fits into Phe19 pocket. Further research by Roche yielded the second generation compound RG7388 (idasanutlin), which is built on the pyrrolidine core [115]. The main optimization step, besides the core, was a change of the mutual configuration of the phenyl rings from cis to trans, which resulted in its reversed occupation in the HDM2 subpockets. Further, to reduce exposure variability and increase the safety and efficiency of idasanutlin, its PEGylated form was developed and tested (RG7775). Another similar inhibitor, AMG-232 was discovered by Amgen Inc. (Thousand Oaks, California, USA) as a result of rational design and optimization steps of the initial lead structure [76]. The idea which lies behind the 
piperidinone scaffold is similar to the ones of nutlins. The isopropyl substituent fills the Leu26 pocket, whereas two trans-orientated chlorophenyl groups occupy the Trp23 and Phe19 pockets (PDB ID: 40AS).

Another numerous class of HDM2 antagonists are spiro-oxindole-3,3'-pyrrolidines, first discovered by Ding et al. at the University of Michigan [116]. Further research yielded the compound MI-63 and closely related MI-219 and MI-319 [117,118]. The analysis of the co-crystal structures of MI-63 analogs suggests that the oxindole part tightly occupies the Trp23 pocket, the aliphatic neo-pentyl substituent fits into Phe19 pocket, and substituted phenyl fits into the Leu26 pocket (for example see PDB ID: 3LBL). Further optimization of spiro-oxindoles led to the discovery of second-generation compounds with reversed stereochemistry and increased affinity [119]. The co-crystal structure of MI-77301 with HDM2 reveals the binding mode similar to its precursors, though it creates additional interactions and induces refolding of the unstructured N-terminal region of HDM2 (PDB ID: 5TRF). Last years provided a group of third-generation spiro-oxindoles, based on dispiropyrrolidine core. The most potent representatives are APG-115 developed by Ascentage Pharma Group (Suzhou, China) [120] and DS-3032b by Daiichi-Sankyo (Tokyo, Japan) [121].

Two additional classes of HDM2 antagonists, being currently tested in clinical trials, were developed by Novartis (Basel, Switzerland). The design is based on the new, 'central valine' concept, which reflects the idea of placing a planar-aromatic ring near the Val93 residue [122]. The first design was based on the dihydroisoquinolinone core and led to the highly potent compound CGM097 [123]. In its co-crystal structure, the molecule fits well into the classical binding pocket on the HDM2 surface (PDB ID: 4ZYF). The Leu26 subpocket is occupied by the alkoxy derivative, the Trp23 subpocket is filled with the 4-chlorophenyl substituent, and the elongated dialkylated aniline locates in the Phe19 subpocket. Further development of the dihydroisoquinoline scaffold resulted in a new class of compounds with the pyrazolo-pyrrolidinone core, represented by the HDM-201 (siremadlin) compound [124]. The rational design enforced the pseudo-equatorial orientation of its 4-chlorophenyl moiety placed in the binding pocket, and as such fulfilled the concept of the 'central valine' model.

Except for small-molecular inhibitors, there are examples of peptide and peptide-mimetics which can interact with HDM2 protein. Noteworthy, one of them, ALRN-6924, discovered by Aileron Therapeutics (Cambridge, Massachusetts, USA), is currently involved in several clinical trials [30]. Its structure is based on the idea of a p53-derived peptide chain, 'stapled' in a helical configuration by the hydrocarbon chain. This approach is beneficial because (i) covalent modification is stabilizing the $\alpha$-helix of the peptide, (ii) the staple moiety protects the peptide from proteolytic degradation, and (iii) cyclization enables the compound to cross the cell membrane. A molecule named as KRT232 delivered by Kartos Therapeutics (Redwood City, California, USA) is in some clinical trials, though its structure has not been disclosed.

\section{Drug Combinations for the Supporting of Anti-Cancer Activity of HDM2 Antagonists}

\subsection{Combinations with DNA-Damaging Agents}

DNA is the most important target for cancer chemotherapy due to the high division rate of cancer cells and improper functioning of DNA repair mechanisms in those cells. For these reasons, any factor causing DNA mutations, i.e., any genotoxic drug or ionizing radiation, would cause serious, irreversible defects in the cell genome that would be more harmful to cancer cells than normal cells. Since DNA damage itself induces a physiological p53 response, the addition of HDM2 antagonists to DNA-damaged cells may assure a prolonged p53 activation by blocking HDM2-negative regulatory loop. At the same time, DNA-damaging agents provide a complete activation of $\mathrm{p} 53$, which cannot be achieved when HDM2 antagonists are used alone.

There are different mechanisms by which therapeutic agents induce DNA damage in the targeted cancer cells (Figure 3) [125]. In this section, the combination therapies of p53/HDM2 antagonists with DNA-damaging agents will be presented according to their mechanism of action. 


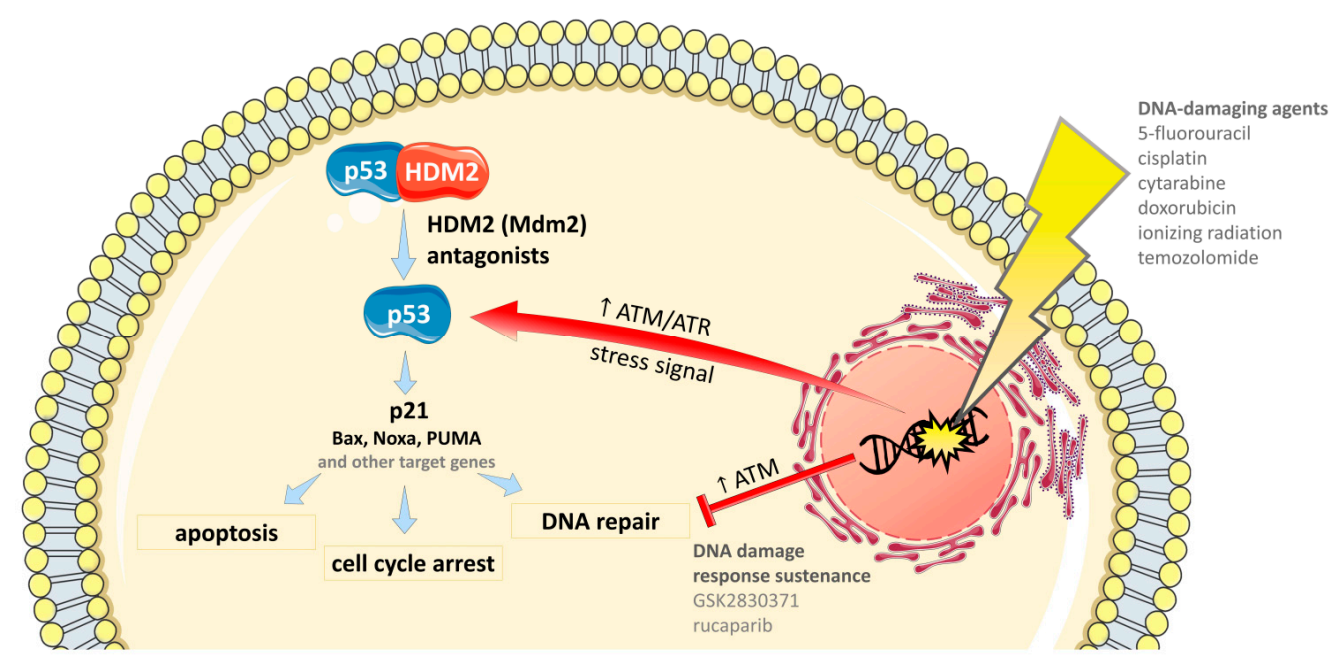

Figure 3. The outline of the combinations of HDM2 antagonists with DNA-damaging agents and the drugs that sustain DNA damage response.

\subsubsection{Alkylating Agents}

Alkylating agents transfer alkyl-groups to DNA and form covalent bonds with nucleobases. This affects the structure and dynamics of DNA, leading to the blockade of DNA replication and RNA transcription, fragmentation of DNA by hydrolytic events and by malfunctions in the action of repair enzymes, as well as nucleotide mispairing. All these events cause DNA damage response that can potentiate the therapeutic effects of HDM2 antagonists.

There are different groups of alkylating agents [125]. Temozolomide (TMZ), which delivers methyl groups to purine bases of DNA, results in the formation of N7-methylguanine and N3-methyladenine. TMZ was evaluated in combination with RG7775 (idasanutlin prodrug) to treat neuroblastoma [55]. The combined treatment has led to the inhibition of tumor growth, which was correlated with the upregulation of genes involved in apoptosis and signal transduction and downregulation of genes involved in DNA replication, mitosis, cell cycle progression and cell division [55]. In another study, TMZ showed an additive antiproliferative effect with HDM2 antagonist CGM097 in neuroendocrine tumor model [32]. Furthermore, idasanutlin was combined with another alkylating agent-busulfan, resulting in consolidation during frontline treatment in neuroblastoma cells [34]. Trabectedin, the compound which alkylates guanine at the N2 position, leads to cell-cycle arrest and p53-mediated apoptosis. This compound was combined with RG7112, which resulted in significant synergy in liposarcoma cells [56].

\subsubsection{Platinum Complexes}

Platinum complexes are molecules that form covalent links between DNA nucleobases, bridged by the platinum atom-containing moieties (a mechanism similar to that of alkylating agents) [126]. This forms monofunctional adducts or inter-strand, intra-strand, or DNA-protein crosslinks [127]. As a consequence, DNA bending and inhibition of DNA replication and transcription are observed [125].

Despite many side effects of cisplatin, it was widely evaluated in many combination therapies with p53/HDM2 antagonists. Combination treatment with cisplatin and nutlin-3a in sarcoma cell lines revealed a clear synergism. It also reduced the negative genotoxic effects without significant changes in antitumor activity. In nasopharyngeal carcinoma cells (NPC) the same therapy showed that nutlin-3 made NPC cells more sensitive to cisplatin-related cytotoxicity; another study indicates that non-small cell lung cancer cell lines are more prone to apoptosis after the combination therapy administration $[39,40,42]$. The treatment with idasanutlin and cisplatin in p53 ${ }^{\mathrm{wt}}$ neuroblastoma cell lines resulted in increased apoptosis, which indicates the synergic effect. In ovarian cancer, the same combination treatment had additive or even synergistic effect, which was confirmed by increased 
p53 activation, enhanced apoptosis and cell cycle arrest [34,37]. MI-319 in combination with cisplatin presented increased cell growth inhibition and apoptosis in pancreatic cancer (PC) cells due to the up-regulation of $\mathrm{p} 73$ protein, which has some overlapping anticancer activities with the p53 protein [38]. AMG-232 combined with cisplatin had notably increased antitumor efficacy in many different cancer cell lines and also in the in vivo studies on mice [35].

Successors of cisplatin, carboplatin and oxaliplatin, were introduced to overcome side effects and resistance to cisplatin [128]. Carboplatin is currently tested in combination with APG-115 in a clinical trial on patients with salivary gland carcinoma (NCT03781986). Carboplatin was also combined with AMG-232 [35], while oxaliplatin was evaluated in combination with MI-219 on p53 ${ }^{\text {wt }}$ Capan-2, HCT-116, and MCF-7 cancer cell lines. In all these three types of tumors, the improved growth inhibition was observed [54].

\subsubsection{Antimetabolites}

Antimetabolites are analogs of naturally occurring compounds that interfere with biochemical processes essential for cell division and survival. Most antimetabolites used in cancer therapy have nucleotide-related structure. These compounds either lead to the inhibition of nucleotide biosynthesis or are incorporated into DNA molecules, leading to impaired DNA processing and mutations [125,129].

Antimetabolites are commonly used to treat cancer and tested also in combination with HDM2 antagonists. Some of the combinations have progressed to the clinical trials. As an example of pyrimidine nucleoside analog, fludarabine (2-fluoro-ara-AMP) has synergic effect with nutlin-3a in chronic lymphocytic leukemia (CLL) by increasing p53 levels, inducing Bax conformational changes and apoptosis in $\mathrm{p} 53^{\mathrm{wt}}$ cells [48]. Another antimetabolite, a purine nucleoside analog, cytarabine, is currently under evaluation in combination with idasanutlin in patients with relapsed or refractory acute myeloid leukemia (AML) (NCT02545283). This study has recently progressed to phase 3, which makes idasanutlin the most advanced HDM2 antagonist in the clinical trials. Cytarabine is also tested in clinical trials with daunorubicin and idasanutlin for safety and efficacy determination in newly diagnosed patients with AML (NCT03850535). A study evaluating the combination of RG7112 with cytarabine in patients with AML is already completed (NCT01635296). Yet another HDM2 antagonist which is evaluated in combination with cytarabine in acute myeloid leukemia or advanced myelodysplastic syndrome patients is stapled peptide ALRN-6924 (NCT02909972). More pyrimidine analogs were also tested: 5-fluorouracil with CGM097 [32], gemcitabine with nutlin-3a [46] and MI-63 [49], decitabine with AMG-232 (NCT03041688), and 5-azacitidine (AZA) with DS-3032b (NCT02319369).

\subsubsection{Topoisomerase Inhibitors}

Topoisomerases (type I and type II) are enzymes that are involved in replication and transcription. Their role is to relax supercoiled DNA. Drugs which target topoisomerases are commonly used to treat cancer $[125,130]$. Topoisomerase inhibitors do not block the catalytic function of the enzyme, but they "poison" them by weakening the enzyme ability to religate DNA and/or by increasing the DNA cleavage [131].

Topotecan and doxorubicin, which are topoisomerase inhibitors, synergize with idasanutlin in p53 ${ }^{\mathrm{wt}}$ neuroblastoma cells [34]. In another study, irinotecan was combined with AMG-232 in the colorectal carcinoma model. The combination therapy showed enhanced anti-cancer activity in comparison to monotherapy [35]. Furthermore, a combination of the topoisomerase II inhibitor, etoposide, with nutlin-3a led to enhanced activation of effector caspases [46]. Etoposide was also combined with another HDM2 antagonist, MI-219. The combinatory treatment revealed that MI-219 synergizes with etoposide by cytotoxicity enhancement and acceleration of the cell killing process [47]. Doxorubicin was evaluated in combination with AMG-232 and nutlin-3a [33,35,45,46]. Another inhibitor from the same class of drugs, daunorubicin, is under evaluation in clinical trials in combination with HDM-201 as the first-line treatment of AML patients or in patients with relapsed/refractory AML (NCT03760445). 
Daunorubicin is also tested in combination with idasanutlin in newly diagnosed AML patients (NCT03850535). Another anthracycline-idarubicin - was tested in vitro with CGM097. In the experiment that the strongest therapeutic effect was achieved when AML cells lines were treated with both agents [44].

\subsubsection{Ionizing Radiation}

Ionizing radiation (IR) is widely used in anti-cancer therapy. Many patients during the cancer treatment receive ionizing radiation, that is either applied alone or in combination with anti-cancer drugs [132]. The radiation has a direct or indirect impact on DNA damage [133]. Direct DNA damage is caused by the introduction of DNA strand breaks, while indirect is mediated by the production of reactive oxygen species (ROS), which in turn lead to many DNA modifications like formation of abasic sites, DNA adducts, single-strand breaks (SSBs) and double-strand breaks (DSBs), DNA-protein crosslinks, base oxidation and base deamination $[125,134]$. Despite the fact that radiation treatment has many side effects [135], it is still a popular approach for the treatment of cancer, especially in combination with therapeutic drugs.

Studies have indicated that IR induces HDM2 expression in a p53-dependent manner. Thus, IR therapies were combined with HDM2 antagonists in an attempt to increase the activity of p53 protein [136]. Nutlin-3 induces senescence and radiosensitivity of laryngeal carcinoma cells (LSCC) retaining wild-type p53 [52]. In another study, nutlin-3 radiosensitized lung cancer cells with wild-type p53, resulting in cell cycle arrest and apoptosis after the combined treatment [137]. This combination was also evaluated in human glioblastoma multiforme, where it resulted in increased apoptosis and senescence. Furthermore, nutlin-3a strengthened the radiation response of glioma cell lines harboring wild-type p53 [53]. Idasanutlin was combined with IR in two models of childhood rhabdomyosarcoma, resulting in increased IR therapeutic efficiency [51]. Another small molecule inhibitor, APG-115, was shown to provide the radiosensitization of p53 wild-type gastric cancer cells. The combination of APG-115 with radiation resulted in cell cycle arrest and apoptosis of these cells [138]. Moreover, AMG-232 is tested in combination with radiation in clinical trials on the patients with glioblastoma (NCT03107780) and soft tissue sarcoma (NCT03217266). Radiation treatment in combination with AMG-232 leads to enhanced tumor reduction. Combination of radiation with AMG-232 was also evaluated in adenoid cystic carcinoma, resulting in tumor growth inhibition and total regression that remained for months after the treatment [50].

\subsection{Combinations with Drugs that Sustain DNA Damage Response}

\subsubsection{DNA Repair Inhibitors}

Poly(ADP-ribose) polymerase (PARP) is a nuclear enzyme, which function is to repair DNA singlestrand breaks. PARP also plays a role in cell proliferation, differentiation, and transformation $[139,140]$. The pharmacological inhibition of PARP leads to the generation of double-strand breaks, which lead to sustained genotoxic stress and apoptosis (Figure 3). One of the nonclinical studies focused on combining nutlin-3a or idasanutlin with a PARP inhibitor, rucaparib, in ovarian cancer cell lines [59]. The combination was proved to be effective in $\mathrm{p} 53^{\mathrm{wt}}$ ovarian cancer cell lines, where it induced apoptosis and cell cycle arrest [59].

\subsubsection{Phosphatases}

Wip1 is a negative regulator of multiple DNA damage response proteins, such as p53, CHK2 (checkpoint kinase 2), histone H2AX, and ATM (Ataxia telangiectasia mutated) (Figure 3) [141]. Overexpression of this protein has been observed in human cancers, particularly of breast and ovarian origin [142]. A Wip1 inhibitor, GSK2830371, potentiated the cytotoxic effect of nutlin-3, idasanutlin, and HDM-201, despite having no cytotoxic activity on its own [15]. The authors explained that the inhibition of Wip1 phosphatase increases the activation of the ATM-mediated network to maintain 
the phosphorylated state of key proteins engaged in DNA damage response [15]. Another group reports similar observations of nutlin-3 and GSK2830371, which when applied together increased p53-mediated tumor suppression and induced senescence in MCF7, U2-OS and HCT116 cells [58]. Additionally, ATSP-7041, a stapled peptide postulated to act as a dual inhibitor of HDM2 and HDM4, synergized with GSK2830371, triggering p53-mediated cell death in Ewing's sarcoma [57].

\subsection{Combinations with Apoptosis-Inducing Agents}

The activation of p53 leads to apoptosis due to the disruption of the balance of pro- and anti-apoptotic proteins (directly or per permeabilization of mitochondria's membrane). This action, however, requires the induction of p53 KILLER mode, which mediates the expression of pro-apoptotic proteins, such as Bax, Apaf-1, and Puma [21,143]. HDM2 antagonists are predominantly inducing the p53 ARRESTER mode, resulting in insufficient apoptosis. Additionally, the overexpression of anti-apoptotic BCL-2 family proteins (i.e., BCL-2, BCL-X, MCL-1) may inhibit the proapoptotic effect of p53 activation [144-146]. Thus, the inactivation/down-regulation of these antiapoptotic proteins or increasing the proapoptotic signaling are rational strategies for enhancing the weak proapoptotic potential of HDM2 antagonists (Figure 4).

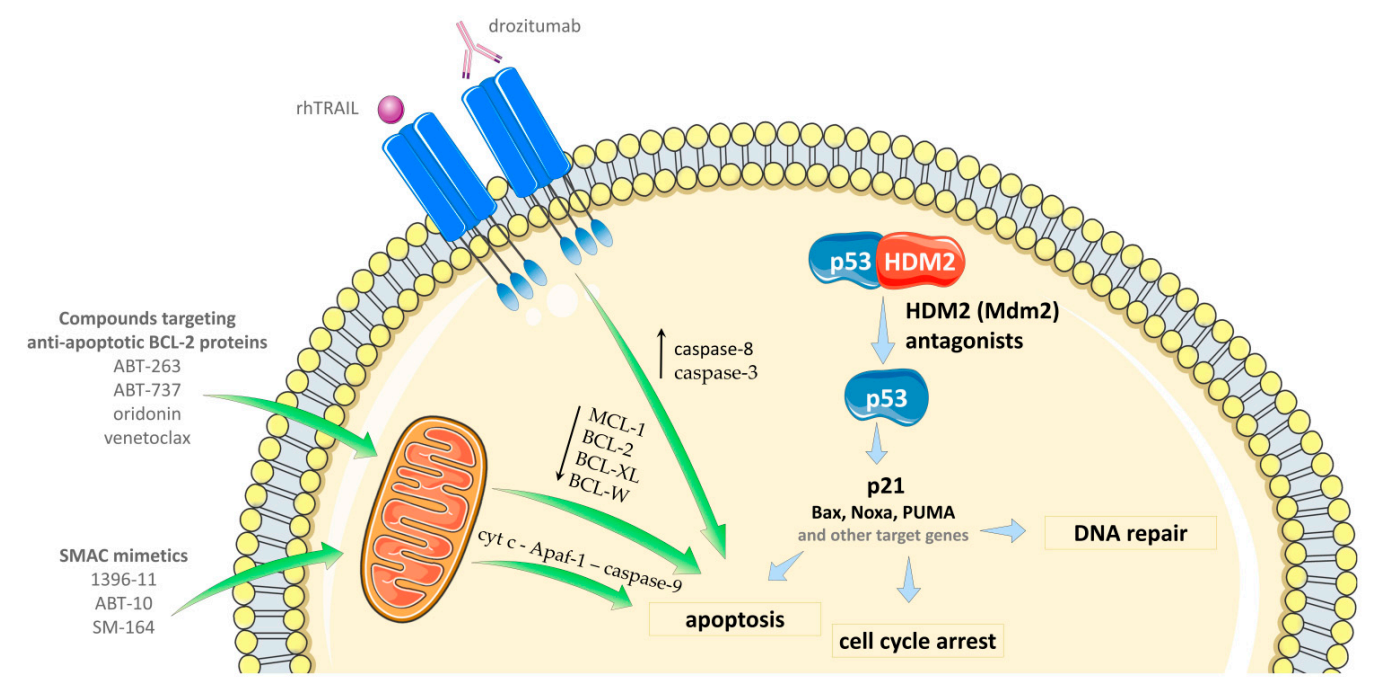

Figure 4. The outline of the combinations of HDM2 antagonists with apoptosis-inducing agents.

\subsubsection{Selective BCL-2 Protein Inhibitors}

Venetoclax (ABT-199/GDC-0199) is a BH3 (Bcl-2 homolog domain) mimetic, which selectively inhibits BCL-2 protein. Venetoclax has revealed significant anti-tumor activity in both pre-clinical and clinical studies [147-149]. The potency of the combined therapy of venetoclax with idasanutlin was investigated both in vitro and in vivo on human cancer cell xenograft mice models of AML and neuroblastoma. The venetoclax/idasanutlin treatment results in the robust down-regulation of the anti-apoptotic protein MCL-1, which is also associated with the resistance to BH3 mimetics in a single therapy $[64,65]$. This mechanism was proposed to explain the observed synergy of venetoclax and idasanutlin treatment [64]. A phase $1 \mathrm{~b} / 2$ clinical study with venetoclax in combination with idasanutlin or cobimetinib (a MEK inhibitor [150]) for the treatment of AML patients is currently running (NCT02670044). In addition, phase $1 \mathrm{~b} / 2$ study aims to assess the dose-escalation and regimen of venetoclax and idasanutlin in combination with monoclonal antibodies against CD20: obinutuzumab for follicular lymphoma (FL), and rituximab for diffuse large B-cell lymphoma (DLBCL) (NCT03135262).

ABT-737 is a BH3 inhibitor of BCL-2, BCL-XL, and BCL-W proteins [151,152]. The combinations of the compound with nultin-3 and MI-63 were investigated by Kojima et al., Gu et al. and Carter et al. [60-62]. The scientists have confirmed that simultaneous treatment with HDM2 antagonists 
and BCL-2 inhibitors results in greater induction of apoptosis and reduction of cell viability of AML cells, multiple myeloma, and blast crisis myeloid leukemia cells. Moreover, it has been proved that the synergistic effect of the combination therapy is independent of the cell cycle, even though the cytotoxicity of each agent alone depends on the cell cycle's phase [60-62]. In another study, performed with acute lymphoblastic leukemia (ALL) and AML patients-derived cell lines, the sublines resistant to BCL-2 inhibitors (ABT-737 and its orally active analog ABT-263-navitoclax) or MDM2 antagonist SAR405838 were developed. The results have shown that in both, the in vitro and in vivo models of acute leukemia, there is no cross-resistance to BCL-2 and HDM2 inhibitors. The combination of ABT-263 and SAR405838, both at $50 \mathrm{mg} / \mathrm{kg}$, resulted in complete tumor regression in $100 \%$ of mice for a period of 44 days, and this treatment regime was much more effective than the single agent therapy [10].

\subsubsection{Agents Downregulating the Level of Anti-Apoptotic BCL-2 Family Proteins}

In addition to the compounds which directly bind BCL-2, combinations with agents that indirectly downregulate the level of anti-apoptotic BCL-2 have been also reported. Nilotinib (AMN107, Tasigna), a Bcr-Abl tyrosine kinase antagonist, inhibits the expression of anti-apoptotic BCL-2 proteins $[153,154]$. In the study designed by Carter et al., nutlin-3 sensitized the patients' chronic myeloid leukemia cells to nilotinib treatment, even though the cells were initially resistant to this drug [61]. Oridonin, a bioactive constituent of a Chinese medicinal herb, which previously had been known as a modulator of BCL-2 levels in melanoma and leukemia, is a potent agent in combination therapy $[155,156]$. Nutlin-3/oridonin treatment leads to robust apoptosis through a substantial increase in the proapoptotic/antiapoptotic BCL-2 proteins ratio in p53 ${ }^{\mathrm{wt}}$ osteosarcoma cells. Moreover, even though oridonin did not increase the level of p53, HDM2, and Puma in the combined strategy nutlin-3 completely abolished the viability of cancer cells. It has been revealed that the synergistic pro-apoptotic effect occurs due to the upregulation of nutlin-3-triggered caspase activation and PARP cleavage [63].

\subsubsection{SMAC Mimetic Compounds}

SMAC (second mitochondria-derived activator of caspase) is a mitochondrial protein that promotes cytochrome c-dependent caspase activation [157]. The mechanism of SMAC action is to promote apoptosis due to the binding to the inhibitor of apoptotic proteins, IAPs, and blocking their inhibitory activity. Thus, SMAC proteins promote the caspase activation in the cytochrome c/Apaf-1/caspase-9 pathway (Figure 4) [157]. So far, several human IAPs have been identified and one of the representatives is known as the protein XIAP (X-linked inhibitor of apoptosis protein) [158].

It has been shown that the level of XIAP is regulated by HDM2 [159]. The hypothesis that the combination of XIAP inhibitors and HDM2 antagonists may lead to the synergistic proapoptotic effects in cancer cells has been verified. The study by Zheng and co-workers has demonstrated that the small molecule XIAP inhibitor, SM-164, does not significantly enhance the potency of MI-219 against lung cancer cells [47]. On the contrary, another group has claimed that the concomitant inhibition of XIAP and p53 activation promotes apoptosis in blasts from the patients with primary AML. The mechanism of the synergy between nutlin-3a and ABT-10 (SMAC mimetic), and nutlin-3a and 1396-11 compound (XIAP inhibitor) has been examined. The researches have revealed that the treatment with either combination, ABT-10/nutlin-3a, and 1396-11/nutlin-3a, induced greater activation of apoptosis signaling pathways and more strongly decreases p21 level via the caspase cleavage, as a result of XIAP inhibition [66]. Also, the cytosolic release of SMAC and increase of effector caspase- 6 following the inhibition of HDM2 were found to be responsible for the increased cell sensitivity to XIAP inhibition [66]. 


\subsubsection{TRAIL Agonists}

TRAIL (TNF-related apoptosis-inducing ligand) is a member of the TNF (tumor necrosis factor) family of cytokines, which acts as one of the most principal extracellular activators of apoptosis [160-162]. TRAIL ligand has an affinity to five receptors, among which DR4 (TRAIL-R1) and DR5 (TRAIL-R2) are able to transmit the apoptotic signal $[161,163]$. The binding of TRAIL to the death receptors DR4 and DR5 engages death-inducing signaling complex, DISC with Fas-associated death domain, FADD and induces cleavage of caspase 8. As a consequence, the process leads to the activation of caspase 3 or the engagement of the mitochondrial apoptotic pathway (Figure 4) [164,165].

Death receptors activate apoptosis pathway in vitro and in vivo after binding the recombinant human TRAIL (rhTRAIL) [166-169]. rhTRAIL induces selective apoptosis in cancer cells and leaves the normal cells unharmed $[170,171]$.

The synergistic interactions of both nutlin-3 and rhTRAIL (dularemin) and nutlin-3 and DR-5-selective TRAIL variant, D269H/E195R [172], have been estimated by the researchers in Groningen [67]. The synergistic proapoptotic effect, induced by enhanced caspase 3 cleavage, has been observed for both combinations. The study has shown that nutlin-3 increases the expression of DR5 on the cell surface in p53 $3^{\mathrm{wt}}$ human non-small cell lung carcinoma, ovarian cancer, and colon cancer cell lines. Relating to this fact, the combination of nutlin-3 with D269H/E195R has been more effective in inducing apoptosis than nutlin-3/rhTRAIL treatment. Furthermore, the nutlin-3/TRAIL agonist/cisplatin triple combination treatment has been explored in the ex vivo tissue slice model of the primary human ovarian cancer. Adding cisplatin as a genotoxic agent to the combination intensified DR5-mediated apoptosis [67].

The combined targeting of HDM2 and TRAIL has also been reported in another study. Urso and colleagues have investigated the synergy between nutlin-3 and rhTRAIL in malignant pleural mesothelioma (MPM) cell lines and RG7112 and rhTRAIL in the in vivo MPM mouse model [68]. The authors speculated that the synergy between nutlin-3a and TRAIL results from the engagement of mitochondrial apoptosis by TRAIL, accompanied by the increased DR5 expression and decreased survivin expression in a response to HDM2 antagonist [68].

\subsection{Combination with Therapy Selectively Targetting Pro-Survival Signaling Pathways}

As our knowledge of the molecular basis of carcinogenesis increases, so do the possibilities of designing new therapies for eradicating the disease. We now know that in cancer cells aberrations occur in many cellular signaling pathways. These pathways regulate, among other processes, survival, growth, and proliferation [173]. The approach to cancer treatment aiming at the selective targeting of these pathways, designated as the targeted therapy, has gained considerable acceptance in the past 20 years. Throughout these years, targeted monoclonal antibodies and synthetic small molecule drugs were extensively tested, in many cases providing much more precise tools than chemotherapy, radiotherapy or other conventional treatments [173-175].

Despite the wide range of anticancer drugs for targeted therapy and many successes in the preclinical research, a great percentage of therapeutics does not provide satisfactory therapeutic outcome when delivered to the patients as single agents [176]. Due to this fact, using two or more agents at the same time as combination therapy became the standard of clinical practice. This also accounts for HDM2 antagonists, since over-activated pro-survival pathways in cancer cells greatly antagonize anti-cancer properties of p53 activation. For this reason, inhibition of pro-survival signaling in cancer cells provides a strong synergism with p53-activating compounds (Figure 5). 


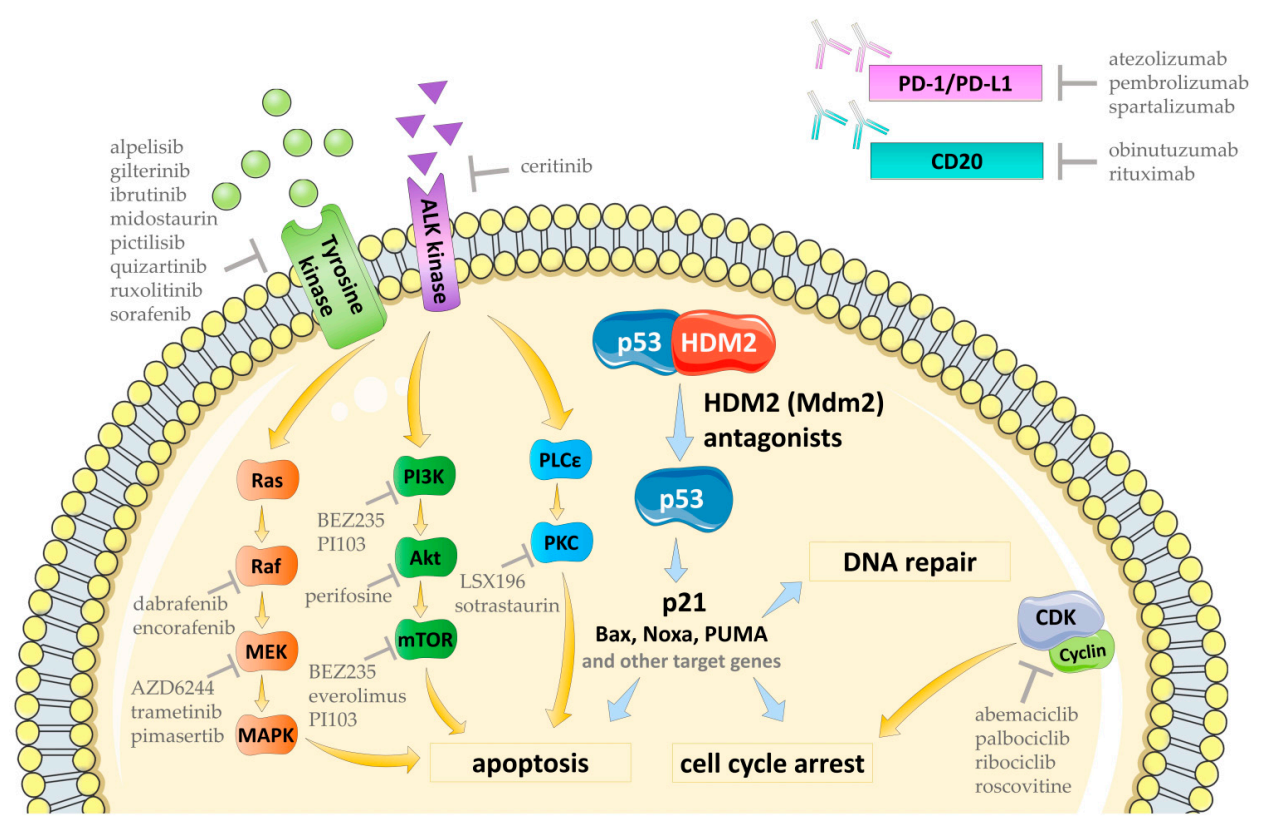

Figure 5. The outline of the combinations of HDM2 antagonists with targeted therapy agents.

\subsubsection{Inhibitors of Tyrosine Kinases}

Tyrosine kinases transfer a phosphate from ATP to tyrosine residues in polypeptides. They function either as extracellular receptors with distinct domains responsible for ligand-binding and kinase activity, or non-receptor proteins located in the cytoplasm [177]. Tyrosine kinase receptors are responsible for initiation, transmission, and regulation of many cellular pathways connected to cell proliferation and survival, such as JAK/STAT, PI3K/Akt/mTOR, and Ras/Raf/MEK/MAPK $[177,178]$. Tyrosine kinase's functions are tightly controlled, but due to mutations in cancer cells frequently their constant activation occurs, providing an unrestrained flow of survival signaling [179].

Many tyrosine kinase inhibitors are currently tested in clinical trials, including several combinations with HDM2 antagonists. FLT3 tyrosine kinase inhibitor, midostaurin (PKC412), is tested in phase 1 and 2 clinical study for acute myeloid leukemia in combination with HDM-201 (NCT03760445). One of the HDM2 antagonists, DS-3032b, is under evaluation in phase 1 clinical trial in combination with quizartinib (NCT03552029). This study also featured AML patients, but only with FLT3 mutated cancers. An additional phase 2a/2b clinical study, currently open for recruitment, focuses on combining KRT232 with ruxolitinib, another inhibitor of tyrosine kinase receptor, which causes an indirect inhibition of JAK/STAT signaling (NCT03669965).

Ibrutinib is a novel inhibitor of Bruton's tyrosine kinase present on B-cells [180]. This inhibitor has been used in combination with nutlin-3 and has exerted a synergistic anti-cancer effect on $\mathrm{p} 53^{\mathrm{wt}}$ and p53 ${ }^{\text {mut }}$ B-leukemic cells [72]. This p53-independent mechanism might be mediated by other proteins from the p53 family, such as p63 and p73 [181]. This effect occurred mainly due to apoptosis induction and cell cycle arrest. When nutlin-3 was combined with sorafenib, a multi-kinase inhibitor, a synergistic cytotoxic effect was observed in AML cell lines [74]. Apart from the common occurrence of apoptosis induction, Zauli et al. also observed an increase in autophagic cell death upon the dual treatment [74]. Sorafenib was also used in combination with nutlin-3 in another study, which tested the co-treatment in renal cell carcinoma models [75]. This treatment resulted in increased apoptosis that was attributed to the increased levels of proapoptotic PUMA protein when the sorafenib and nutlin-3 cotreatment was applied [75]. Midostaurin, was shown to synergize with CGM097 in AML cell models along with apoptosis induction [51,73]. A more selective inhibitor of FLT3, quizartinib (ACC220), also showed similar synergy [73]. CGM097 and HDM-201 in combination with FLT3 inhibitors, midostaurin, BKM120 (buparlisib), GDC-0941 (pictilisib), BYL719 (alpelisib) and ASP2215 (gilterinib) also exhibited a 
moderate to strong synergistic response in AML cell lines [44]. Simultaneous activation of p53 by HDM2 blockade and ALK (anaplastic lymphoma kinase) inhibition worked synergistically in suppressing the growth of different ALK-amplified or mutated neuroblastoma cell lines [69]. The researchers used CGM097 and ceritinib, a second generation ALK inhibitor first in in vitro studies, which were then followed by mouse xenograft experiments. The combination was effective and resulted in tumor regression throughout the time of the treatment in three out of five models used. The authors point out that HDM2 inhibition is especially valuable for the treatment of MYCN-amplified neuroblastoma cell lines, as these cells show remarkable sensitivity to MDM2 antagonists in vitro [69].

\subsubsection{Ras/Raf/MEK/MAPK Pathway Inhibitors}

One of the best characterized cellular pathways in cell biology is the mitogen-activated protein kinase pathway, composed of Ras/Raf/MEK/MAPK proteins. This pathway is responsible for many critical functions of the cell response to extracellular stimuli, such as cytokines, growth factors or mitogen binding to their receptors localized in the cell membrane $[182,183]$. The components of this pathway play a very important role in the genesis of cancer, which has been reported many times before [183-185]. p53 and the MAPK components are the most frequently mutated tumor suppressor and oncogene pathways in human cancers [81]. For this reason, there is a great potential in simultaneous targeting of these two pathways to provide useful therapeutic approaches. For example, MEK inhibition seems to result in transcriptional and posttranscriptional downregulation of the HDM2 gene, which in turn leads to lower HDM2 protein levels and increased activity of p53 [186].

The inhibitors of the Ras/Raf/MEK/MAPK pathway are used in combination with various HDM2 inhibitors in four clinical trials, one of which is still recruiting. AMG-232 was tested in combination with trametinib (GSK1120212), a selective MEK1 and MEK2 inhibitor in a phase 1b clinical trial on the AML patients (NCT02016729). Another clinical study (NCT02110355) featured AMG-232 for the treatment of metastatic melanoma along with trametinib and dabrafenib. The early data for AMG-232 combined with trametinib or dabrafenib suggested promising pharmacokinetic properties and potential antitumor activity [78]. HDM-201 has also been combined with trametinib in a clinical study for the treatment of advanced/metastatic RAS/RAF mutant and p53 ${ }^{\mathrm{wt}}$ colorectal carcinomas (NCT03714958). This phase 1 study sponsored by Centre Léon Bérard is currently recruiting and is estimated to be completed in late 2020. A phase 1 clinical trial of yet another HDM2 antagonist, SAR405838 in combination with pimasertib, a selective MEK1/2 inhibitor, has been conducted for the treatment of malignant neoplasm (NCT01985191). The patients suffered from different tumor types, i.e., colorectal, lung, melanoma. The trial has so far defined the maximum tolerated dose of the drugs in combination and provided preliminary results on the antitumor activity of this combination [81].

Recently, $\mathrm{Wu}$ and co-workers confirmed the synergistic effect of trametinib with three different HDM2/p53 interaction inhibitors-nutlin-3, idasanutlin, and HDM-201-in cutaneous melanoma cell models [82]. All combinations resulted in a significant increase of p53 level as well as its phosphorylation status. The authors propose that the synergy results from the sustained activation of ATM following trametinib administration, which maintains high phosphorylation status and activity of p53, released by HDM2 antagonists. As a result, increased levels of apoptotic and cell-cycle arrested $\mathrm{p} 53^{\mathrm{wt}}$ cells (but not p53 ${ }^{\mathrm{mut}}$ ) were also reported, showing a clear synergy of trametinib with HDM2 antagonists [82]. A significant synergistic effect of combined HDM2/p53 and MEK blockade on cell growth inhibition and apoptosis induction was observed by Zhang et al. in AML cell lines [77]. This group used nutlin-3a and a second generation allosteric MEK1/2 inhibitor AZD6244 (AstraZeneca, ARRY-142886, selumetinib), which showed high selectivity and anti-tumor efficiency both in pre-clinical and clinical studies [187]. The MEK inhibitor itself has shown moderate proapoptotic effect in OCI/AML3 and MOLM13 cells, which became significant upon combining selumetinib with nutlin-3a [77]. CGM097 has been tested for synergy in combination with LGX818 (NVP-LGX818, encorafenib), a BRAF inhibitor [80]. The authors reported a strong synergistic response to combination treatment in both the in vitro viability assays on BRAFmut melanoma cells, 
and tumor growth in vivo, to the point of long-lasting tumor regressions. The proposed rationale for this synergism was the induction of a complementary set of anti-proliferative and apoptosis stimulating molecules by the combination of the compounds, since CGM097 induces p21 and Bax expression, while NVP-LGX818 causes the induction of p27 and Bim [80]. CGM097 seems to exhibit a synergistic apoptotic effect also when combined with selumetinib [73].

\subsubsection{PI3K/Akt/mTOR Pathway Inhibitors}

$\mathrm{PI} 3 \mathrm{~K} / \mathrm{Akt} / \mathrm{mTOR}$ pathway has very important functions in controlling various cellular processes. Among them are transcription and translation, metabolism, angiogenesis, cell cycle and apoptosis $[188,189]$. These processes are important both in physiological and in pathological conditions and are very often deregulated during cancer formation and progression [190].

Perifosine, a synthetic alkyl-phospholipid, which is known to inhibit Akt, has been combined with nutlin-3 and showed increased antileukemic activity [86,191]. The combination has been tested on six different leukemia cell lines and resulted in greater apoptosis and p53 protein expression induction in $\mathrm{p}^{53^{\mathrm{wt}}}$ cell lines [86]. Idasanutlin and BEZ235, a PI3K and mTOR inhibitor, elicited a strong therapeutic response in well-differentiated/dedifferentiated liposarcomas, which corresponded with consistent induction of apoptosis and p53 level upon the combined treatment [83]. These findings were then confirmed on mouse xenograft models, in which the dual therapy caused significant tumor regression [83]. A different research group has found that PI3K/mTOR inhibitor PI103 causes a reduction in p53 level, which has been raised when a combination with nutlin-3 was applied [85]. Synergistic effects of HDM2 antagonist AMG-232 with many PI3K/Akt/mTOR and Ras/Raf/MEK/MAPK inhibitors were also reported on twenty different human cancer cell lines and in RKO tumor xenograft in vivo experiments [79]. A great therapeutic effect was observed upon combining HDM2 antagonist AMG-232 with MEK inhibitor PD0325901 and PI3K inhibitor AMG511 in triple therapy [79]. Dual therapy with CGM097 and everolimus, a well-known mTOR inhibitor, showed an additive antiproliferative effect on GOT1 cells [32].

\subsubsection{CDK Inhibitors}

Alterations in cell cycle control occur frequently in many types of human cancers. For this reason, inhibitors of cyclin-dependent kinases (CDKs) became a very important group of anti-cancer drugs [192]. In cancer cells, CDK regulatory pathways are constantly active, leading to the omission of critical cell cycle checkpoints, uncontrolled growth, and proliferation [192].

One combination therapy using an HDM2/p53 interaction inhibitor and a CDK inhibitor has made it into the clinical trials. HDM-201 has been combined with a selective CDK4/6 inhibitor ribociclib (LEE011) from Novartis for the treatment of 74 adults with liposarcomas (NCT02343172). This Phase $1 \mathrm{~b} / 2$ study aims to assess the maximum tolerated dose and the safety and efficacy of the combination for liposarcoma patients.

The possibilities of combining the inhibitors targeting HDM2 and CDKs are being continuously explored in preclinical research. The combination of idasanutlin with palbociclib, a highly selective inhibitor of CDK4/ 6 widely used in clinical trials, was reported to wield great antitumor properties in dedifferentiated liposarcomas when compared to monotherapy [88]. Simultaneous treatment caused a significant increase in apoptosis in the in vitro studies, which was later confirmed by tumor volume regression in the in vivo experiments with a mice xenograft model of dedifferentiated liposarcoma [88]. However, Sriraman et al. showed that in five different cell lines derived from human liposarcoma, HDM2 inhibitor nutlin-3a and CDK4/6 inhibitors palbociclib, ribociclib and abemaciclib not only fail to synergize, but even seem to antagonize each other's therapeutic effects, despite the co-amplification of HDM2 and CDK4 genes in the used models [87]. The authors concluded that employing both therapies simultaneously may, in fact, be counterproductive and result in an unfavorable outcome for patients [87]. These findings seem to contradict the previous report by Laroche-Clary et al. [88]. Roscovitine (CY-202, seliciclib), a wide-range CDK inhibitor 
with strong activity towards CDK1, CDK2, CDK5, and CDK7, and weak towards CDK4 and CDK6, showed a considerable synergy with nutlin-3a [90,193]. The effect was visible as an additive reduction of cell viability and induction of p53-dependent apoptosis. The same researchers reported that the effect was enhanced when combining nutlin-3a and roscovitine with DRB, an adenosine analog [90]. Roscovitine and nutlin-3 were additionally found to pharmacologically synergize in neuroblastoma [89].

\subsubsection{PKC Inhibitors}

Another class of protein kinases extensively studied in the context of cancer is the family of Protein Kinases C (PKC), composed of at least twelve members [194,195]. Different isoenzymes of PKC affect many cell functions, such as proliferation, migration, adhesion, survival and malignant transformation, and are crucial players in carcinogenesis and maintenance of malignant phenotype of cancer cells [194,196]. Overexpression of PKCs is often observed in cancer [194,197].

A therapeutic combination of LXS196, a small-molecule drug that binds and inhibits PKC, and HDM-201 is being determined in the form of an active clinical trial in metastatic uveal melanoma patients (NCT02601378). The combination of PKC inhibitor and HDM2 antagonists has been tested for uveal melanoma also in nonclinical research. Co-treatment using CGM097 and a PKC inhibitor sotrastaurin (AEB071) was reported by Carita et al. to decrease the tumor volume in patient-derived xenograft mouse models [91]. The same tendency to stimulate cell death by apoptosis has also been confirmed in uveal melanoma cell lines [91].

\subsection{The Combination with Anti-PD-/PD-L1 and Anti-CD20 Therapeutic Antibodies}

Monoclonal antibodies (mAbs) constitute a tremendous portion of anti-cancer agents. Targeted therapies based on monoclonal antibodies that block numerous oncogenic pathways are widely studied [198,199]. mAbs are the most successful therapeutic agents, for both, the solid tumors [200], and leukemias or lymphomas [201]. The unprecedented potency of immunoglobulins has been confirmed by hundreds of clinical trials (according to the 2017 GlobalData report [202]).

A number of combinations of HDM2 antagonists with monoclonal antibodies are undergoing clinical trials. Among them, the therapies with mAbs targeting PD-1/PD-L1 interaction or B-lymphocyte antigen CD20 have their primacy (Figure 5).

In June 2019 there have already been three $1 \mathrm{~b} / 2$ phase clinical studies regarding the combination of HDM2 with PD-1 or PD-L1 inhibitors. In 2016, Novartis Pharmaceuticals has started clinical trials with the combination of HDM-201 and PDR001 (spartalizumab, anti-PD-1 antibody) to characterize the dose escalation for colorectal cancer and renal cell carcinoma treatment (NCT02890069). Pembrolizumab (Keytruda), another anti-PD-1 antibody approved by the FDA across a range of cancers [203] is tested with APG-115 in patients with advanced solid tumors and unresectable or metastatic melanomas (NCT03611868). Another active clinical trial involves the studies on the safety and tolerability of idasanutlin in combination with atezolizumab (Tecentriq, anti-PD-L1 antibody, a drug approved as a single therapy for various cancers [203]) and MEK inhibitor, cobimetinib. The study has been running since 2018 and is currently in the recruitment phase for the patients who suffer from metastatic estrogen receptor-positive breast cancer (NCT03566485).

Rituximab (MabThera ${ }^{\circledR}$ ) and obinutuzumab (Gazyva ${ }^{\circledR}$ ) are humanized anti-CD20 mAbs characterized by a distinct mechanism of action. The scientists speculate on the superiority of these two biologics over each other [204]. Pre-clinical data suggests that obinutuzumab is more efficient than rituximab in depleting B cells [205] and has a better toxicological profile, while rituximab therapy causes increased resistance generation [206,207]. Nevertheless, both mAbs have been approved for cancer therapy.

Phase $1 \mathrm{~b} / 2$ clinical trials of rituximab and obinutuzumab in combination with idasanutlin have been conducted by Hoffmann-La Roche. The first study started in 2015 and involved the treatment with idasanutlin and obinutuzumab in the FL patients and the idasanutlin/rituximab combination 
in DLBCL participants (NCT02624986). The second study is running and aims at determining the regimen for idasanutlin and venetoclax (selective BCL-2 protein inhibitor, see the previous section) in dual and triple combinations with obinutuzumab and with rituximab for FL and DLBCL patients (NCT03135262).

In addition, the synergistic effect on cell death induction has been shown for obinutuzumab and nutlin-3 in the preliminary in vitro studies with chronic lymphocytic leukemia cell lines [92]. Roche has strengthened the idea of combination therapy with anti-CD20 mAbs and HDM2 antagonist for the patients with CD20-positive B-cell malignancies. The study reported the combined obinutuzumab/idasanutlin treatment to be superior to single therapy with $\mathrm{mAb}$ in mantle cell lymphoma (MCL) and DLBCL xenograft models [93].

The efficacy of drozitumab, a human mAb against DR5 was evaluated in a combination treatment with nutlin-3. HDM2 antagonist has augmented the apoptotic response to drozitumab in vitro in a panel of sarcoma cell lines and ex vivo human sarcoma patients. The scientists have postulated that the key factor that contributes to the synergistic effects between these molecules is upregulation of DR5 receptor expression following the p53 activation [94]. However, the development of drozitumab has been discontinued in 2010 [208].

\subsection{The Combinations with Miscellaneous Anti-Cancer Agents}

\subsubsection{Proteasome Inhibitors}

Proteasome serves as the main center of protein degradation in cells. The proteasome-dependent degradation of tumor suppressors, such as p53 [188,190], and other proteins involved in anti-cancer response (i.e., IKB and p44/42 MAPK) [209] is correlated with multiple types of cancer [210]. Therefore, inhibition of proteasome activity is a promising anti-cancer strategy (briefly reviewed in $[210,211])$.

Bortezomib (Velcade ${ }^{\circledR}$ ) was the first proteasome inhibitor designed and approved for cancer treatment, more specifically for multiple myeloma patients [212]. The synergistic effect of bortezomib in combination with HDM2 inhibitors has been evaluated on a variety of cancer types in vitro. Bortezomib has exhibited anti-cancer activity against mantle cell lymphoma, and the addition of nutlin-3 has resulted in synergistic cytotoxicity regardless of mutational p53 status in cancer cell lines [97]. The p53-independent effect of the combination has been associated with an increased level of p73 protein, a p53 homolog. p73-mediated induction of p21, Puma and Noxa expression may account for the observed cell-cycle arrest and apoptosis [97]. An additive cytotoxic effect of nutlin-3 and bortezomib has been reported on bortezomib-sensitive multiple myeloma (MM) cell lines [95]. The authors explain that the combination of HDM2 inhibition and proteasome inhibition not only increases the stability and levels of p53 but also blocks its ubiquitination and transcriptional inactivation, thus making p53 more functional [95]. In another study, the scientists have shown the synergistic cytotoxic activity of the compounds in MM cells. The authors report the induction of apoptotic signaling defined as the cleavage of PARP, caspase- 8 and caspase- 3 and a modest cleavage of caspase-9 [96]. Additionally, p53-induced repression of the anti-apoptotic protein, survivin was observed [96]. In breast, prostate, colon, and thyroid cell lines, the nutlin-3/bortezomib combination has triggered the synergistic cytotoxic effect. Furthermore, the scientists have postulated that, as a consequence of nutlin-3 action, molecular pathways associated with poorer responsiveness to bortezomib may be counteracted [95].

Ixazomib citrate and carfilzomib are next-generation proteasome inhibitors, that are used in experimental combination therapies with HDM2 antagonists. Ixazomib citrate is currently tested in a combination with idasanutlin and dexamethasone. Phase 1 and 2 clinical study is performed to estimate optimum regimens in treating patients with MM that has returned after a period of improvement (NCT02633059). National Cancer Institute conducts the phase 1 trial studies on AMG-232 treatment when given together with carfilzomib and other drugs used in 
chemotherapy: lenalidomide and dexamethasone. The patients suffering from hypercalcemia, plasmacytoma, recurrent plasma cell myeloma, and refractory cell myeloma are currently being recruited (NCT03031730).

The effect of MG-132 (one of the early proteasome inhibitors) and nutlin-3 on schwannoma cells has been assessed by Chen and colleagues. They have demonstrated that the differences in the expression of merlin, which is a tumor suppressor protein, in cancer cultures explain the functional diversity in response to nutlin-3 treatment [98]. It has been proved that dual therapy of nutlin-3/MG-132 narrows the differences in the sensitivity to nutlin-3 in schwannoma cells. In addition, in vivo experiment with human xenograft model of schwannoma has revealed that the small-molecules work together to impose apoptosis [98].

\subsubsection{Histone Deacetylase Inhibitors}

Epigenetic regulation is also used as a possible therapeutic approach for cancer treatment. In this therapy, histone deacetylases (HDAC) inhibitors play a major role, with several potent compounds being tested in clinical trials [213]. Valproic acid (VPA) inhibits the action of class I HDACs [214]. The combination with nutlin-3 increased the level of apoptosis and autophagy in p53 ${ }^{\mathrm{wt}}$ AML cell line MOLM-13 and caused significant tumor regression in a MOLM-13 mouse model [100]. Suberoylanilide hydroxamic acid (SAHA, vorinostat, MK0683) is another HDAC inhibitor. It has been used in combined therapy with idasanutlin, resulting in synergy in apoptosis induction in AML cell lines regardless of their p53 status [99].

\subsubsection{Antibiotics}

Antibiotics are typically used to treat bacterial infections. However, some classes of antibiotics inhibit the division of proliferating eukaryotic cells and thus are also explored in the therapy of cancer [215-217]. Some compounds representative for this group of molecules were studied in combination therapies with HDM2 antagonists. One example is actinomycin D, a well-known transcription inhibitor widely used to treat cancer [218]. Actinomycin D inhibits RNA synthesis by blocking DNA-dependent RNA polymerase. Nutlin-3 combined with actinomycin D resulted in the enhancement of antitumor activity in rhabdomyosarcoma cells with wild-type p53 [101]. In another study with the same combination, the synergic effect on cancer cell lines has been confirmed [102]. Nutlin-3a binds to HDM2 and releases p53, while actinomycin D stimulates p53 phosphorylation and accumulation via a mechanism which engages HDM2 high expression. Authors have shown that the combination therapy results in the enhanced p53 activation with phosphorylation of Ser46 residue, which is a marker of proapoptotic p53 KILLER mode [102].

\subsubsection{Zinc}

Zinc has an essential impact on p53. The p53 protein binds to DNA by a domain which is stabilized by a zinc atom, which is why its role is so important in forming p53 DNA-binding domain complex [219]. Metal chelators have the ability to remove zinc from p53, what in turn leads to 'mutant-like' p53 form which cannot specifically bind to DNA [220]. Zinc has been tested in combination with HDM2 inhibitor, MI-219, in colon and breast cancer cells. The scientists observed a significant increase of MI-219-induced apoptosis in the treated cells. Furthermore, this phenomenon was reversible by a zinc chelator, TPEN ( $, \mathrm{N}_{1} \mathrm{~N}^{\prime}, \mathrm{N}^{\prime}$-tetrakis(2-pyridinylmethyl)-1,2-ethanediamine), which clearly suggests a crucial zinc role in this process [38].

Zinc metallochaperones (ZMCs) are a new class of mutant p53 reactivators [221]. In general, the function of metallochaperones is to shuttle metal ions to intracellular proteins [222]. ZMCs are small-molecule metal ion chelators that have the ability to donate zinc to mutant p53 which lacks $\mathrm{Zn}^{2+}$ [221]. Many studies indicate that ionizing radiation and chemotherapy work better on wild-type p53 tumors [223]. This became the rationale for combining these therapies with drugs which reactivate p53 in p53-mutated cancers. There have been studies conducted on the combination 
of nutlin with ZMC1 (thiosemicarbazone). The authors hypothesized that if nutlin could stabilize the levels of mutant p53, this will result in that ZMC1 should have more mutant p53 to reactivate and in turn kill more cancer cells. The results of this combination therapy on immunodeficient mice bearing TOV112D xenograft tumors have shown a significant synergistic effect on the tumor growth inhibition in comparison to the single treatment [103].

\subsubsection{Heat Shock Protein Inhibitor}

Heat shock proteins (HSPs) are responsible for the proper folding of synthesized proteins or refolding under denaturating conditions [224]. HSPs have an impact on protein degradation in proteasome [225]. Cancer cells require HSP90 protein for the maintenance of mutated proteins. In patients with acute myeloid leukemia, there is a high expression of HSPs [226]. Inhibitors of Hsp90 increase the acetylation of p53 and inhibit HDMX, indicating the potential synergy with HDM2 antagonists in enhancing p53-mediated apoptosis. Combination treatment of Hsp90 inhibitor geldanamycin and nutlin-3 showed synergistic effect by inducing apoptosis in AML cell lines and primary AML cells [104]. The results also revealed that nutlin-3 stimulates acetylation of p53, histones, and heat shock proteins [104].

\subsubsection{ATPase Inhibitors}

Archazolid is a myxobacteria-derived ATPase inhibitor. The compound regulates anoikis resistance and exhibits anti-tumor and anti-metastatic activity in hepatocellular carcinoma (HCC) and breast cancer in both in vivo and in vitro models [227-229]. Schneider and colleagues have reported that the archazolid/nutlin-3 combination results in synergistically induced cell death in p53 ${ }^{\text {wt }}$-harboring cancer cells in vitro and in a glioblastoma xenograft model [105]. The pro-apoptotic effect was related to the activation of Bax and IGFBP3 (insulin-like growth factor-binding protein 3) pathways. It has also been disclosed that the observed synergy might be a consequence of the reduction of glycolysis due to the intensified downregulation of TIGAR (TP53-inducible glycolysis and apoptosis regulator) mRNA level and also diminished Glu1 levels and glucose uptake in cancer cells [105].

\subsubsection{Mitotic Inhibitors}

Mitotic inhibitors, especially spindle poisons, are claimed to have a relatively low genotoxicity score [230]. Spindle poisons were evaluated in pre-clinical trials as a single treatment, as well as in combination with HDM2/p53 antagonists. Vincristine in combination with nutlin-3 increased anti-cancer activity in rhabdomyosarcoma (RMS) tumors harboring wild-type p53 [101]. Vincristine was also combined with RG7112 in infant mixed lineage leukemia-rearranged acute lymphoblastic leukemia (MLL-ALL). There was a therapeutic enhancement in comparison compared to the single therapy with RG7112 [106]. Paclitaxel, another example of spindle poisons, is currently under evaluation in clinical trials in combination with ALRN-6924 (NCT03725436). This study is being conducted on patients with advanced, metastatic, or unresectable solid tumors. It is a promising strategy of anti-tumor therapy for patients with tumors which cannot be eliminated by the surgery.

\subsubsection{Other Agents}

Interestingly, metformin, a drug widely used in the treatment of type 2 diabetes mellitus and polycystic ovary syndrome, seems to possess anti-tumor properties via indirect mTOR protein inhibition [231,232]. One of the studies focused on combining metformin with nutlin-3a, and this dual treatment of $\mathrm{p} 53^{\mathrm{wt}}$ mesothelioma cells showed additive growth inhibition of the cells [107]. A combination of nutlin-3 and Tanshinone IIA, a phytochemical isolated from the Chinese medicinal herb Salvia miltiorrhiza, seems to show a synergistic effect when used together in AML cell lines. The authors reported increased cytotoxicity, apoptosis, autophagic cell death and cell cycle arrest, as well as p53 upregulation and PI3K/Akt/mTOR pathway inhibition in the in vitro leukemia models 
and cell sampled from patients [108]. Within the antimetabolites group, there are analogs of folic acid such as methotrexate. The compound inhibits key enzymes in nucleotide biosynthesis, leading to cell-cycle arrest and apoptosis. Methotrexate combined with nutlin-3a resulted in a decline of cytotoxicity evoked by nutlin-3 [42]. One additional study has shown that stapled peptide ATSP-7041 has an additive effect on cytotoxicity and induction of cell death in Ewing's sarcoma cells with USP7 inhibitor P5091 [57].

\section{Conclusions}

Undeniably, p53 is amongst the most important and best-studied proteins in the context of cancer. Since the discovery of the cancer-preventing potential of p53 and its ubiquitous inactivation in all types of cancers, multiple approaches aiming at its reactivation have been proposed [233]. The development of small-molecule HDM2 antagonists has become one of the leading strategies in this field since it was estimated that in around half of the cancers the wild-type status of the TP53 gene is preserved.

Following the initial discovery of the nutlins, multiple chemical scaffolds were tested for the ability to release p53 from HDM2 inhibition [31]. These extensive studies have produced several extraordinary compounds, with proven bioactivity and optimized pharmacological properties that were applicable for clinical trials. By that time, however, extensive evidence pointing to serious limitations of the anticancer properties of HDM2 antagonists has accumulated, as these compounds force $\mathrm{p} 53$ release without providing appropriate proapoptotic context. It seems that this judgment has been well acknowledged for the past years. This is manifested by the extensive investigation of drug combinations designed in order to support the anticancer properties of HDM2 antagonists (Figure 1). Also, this trend has determined the direction of the experimental clinical trials, where multiple combinations are tested in a search for potential therapeutic synergies. It seems only a matter of time that some combinations will confirm their clinical relevance and will constitute new regimes for the treatment of cancer patients.

Funding: This research was funded by Grants UMO-2016/21/D/NZ7/00596 and UMO-2014/12/W/NZ1/00457 from the National Science Centre, Poland. J.K. acknowledges the support of InterDokMed project no. POWR.03.02.00-00-I013/16.

Acknowledgments: Figures 2-5 were created using Servier Medical Art templates, which are licensed under a Creative Commons Attribution 3.0 Unported License; https://smart.servier.com/. All data for clinical studies was based on information from U.S. National Library of Medicine ClinicalTrials.gov, access July 2019; https://clinicaltrials.gov/.

Conflicts of Interest: The authors declare no conflict of interest. The funders had no role in the design of the study; in the collection, analyses, or interpretation of data; in the writing of the manuscript, and in the decision to publish the results.

\section{References}

1. Joerger, A.C.; Fersht, A.R. The p53 Pathway: Origins, Inactivation in Cancer, and Emerging Therapeutic Approaches. Annu. Rev. Biochem. 2016, 85, 375-404. [CrossRef] [PubMed]

2. Khoo, K.H.; Verma, C.S.; Lane, D.P. Drugging the p53 pathway: Understanding the route to clinical efficacy. Nat. Rev. Drug Discov. 2014, 13, 217-236. [CrossRef] [PubMed]

3. Catizone, A.N.; Good, C.R.; Alexander, K.A.; Berger, S.L.; Sammons, M.A. Comparison of genotoxic versus nongenotoxic stabilization of p53 provides insight into parallel stress-responsive transcriptional networks. Cell Cycle 2019, 18, 809-823. [CrossRef] [PubMed]

4. Tovar, C.; Rosinski, J.; Filipovic, Z.; Higgins, B.; Kolinsky, K.; Hilton, H.; Zhao, X.; Vu, B.T.; Qing, W.; Packman, K.; et al. Small-molecule MDM2 antagonists reveal aberrant p53 signaling in cancer: Implications for therapy. Proc. Natl. Acad. Sci. USA 2006, 103, 1888-1893. [CrossRef] [PubMed]

5. París, R.; Henry, R.E.; Stephens, S.J.; McBryde, M.; Espinosa, J.M. Multiple p53-independent gene silencing mechanisms define the cellular response to p53 activation. Cell Cycle 2008, 7, 2427-2433. [CrossRef] 
6. Huang, B.; Deo, D.; Xia, M.; Vassilev, L.T. Pharmacologic p53 activation blocks cell cycle progression but fails to induce senescence in epithelial cancer cells. Mol. Cancer Res. 2009, 7, 1497-1509. [CrossRef] [PubMed]

7. Michaelis, M.; Rothweiler, F.; Barth, S.; Cinatl, J.; van Rikxoort, M.; Löschmann, N.; Voges, Y.; Breitling, R.; von Deimling, A.; Rödel, F.; et al. Adaptation of cancer cells from different entities to the MDM2 inhibitor nutlin-3 results in the emergence of p53-mutated multi-drug-resistant cancer cells. Cell Death Dis. 2011, 2, e243. [CrossRef] [PubMed]

8. Aziz, M.H.; Shen, H.; Maki, C.G. Acquisition of p53 mutations in response to the non-genotoxic p53 activator Nutlin-3. Oncogene 2011, 30, 4678-4686. [CrossRef]

9. Wei, S.J.; Joseph, T.; Sim, A.Y.L.; Yurlova, L.; Zolghadr, K.; Lane, D.; Verma, C.; Ghadessy, F. In vitro selection of mutant HDM2 resistant to Nutlin inhibition. PLoS ONE 2013, 8, e62564. [CrossRef]

10. Hoffman-Luca, C.G.; Ziazadeh, D.; McEachern, D.; Zhao, Y.; Sun, W.; Debussche, L.; Wang, S. Elucidation of Acquired Resistance to Bcl-2 and MDM2 Inhibitors in Acute Leukemia In Vitro and In Vivo. Clin. Cancer Res. 2015, 21, 2558-2568. [CrossRef]

11. Jung, J.; Lee, J.S.; Dickson, M.A.; Schwartz, G.K.; Le Cesne, A.; Varga, A.; Bahleda, R.; Wagner, A.J.; Choy, E.; de Jonge, M.J.; et al. TP53 mutations emerge with HDM2 inhibitor SAR405838 treatment in de-differentiated liposarcoma. Nat. Commun. 2016, 7, 12609. [CrossRef] [PubMed]

12. Drummond, C.J.; Esfandiari, A.; Liu, J.; Lu, X.; Hutton, C.; Jackson, J.; Bennaceur, K.; Xu, Q.; Makimanejavali, A.R.; Del Bello, F.; et al. TP53 mutant MDM2-amplified cell lines selected for resistance to MDM2-p53 binding antagonists retain sensitivity to ionizing radiation. Oncotarget 2016, 7, 46203-46218. [CrossRef] [PubMed]

13. Chapeau, E.A.; Gembarska, A.; Durand, E.Y.; Mandon, E.; Estadieu, C.; Romanet, V.; Wiesmann, M.; Tiedt, R.; Lehar, J.; de Weck, A.; et al. Resistance mechanisms to TP53-MDM2 inhibition identified by in vivo piggyBac transposon mutagenesis screen in an Arf-/- mouse model. Proc. Natl. Acad. Sci. USA 2017, 114, 3151-3156. [CrossRef] [PubMed]

14. Skalniak, L.; Kocik, J.; Polak, J.; Skalniak, A.; Rak, M.; Wolnicka-Glubisz, A.; Holak, T.A. Prolonged Idasanutlin (RG7388) Treatment Leads to the Generation of p53-Mutated Cells. Cancers 2018, 10, 396. [CrossRef] [PubMed]

15. Wu, C.-E.; Esfandiari, A.; Ho, Y.-H.; Wang, N.; Mahdi, A.K.; Aptullahoglu, E.; Lovat, P.; Lunec, J. Targeting negative regulation of $\mathrm{p} 53$ by MDM2 and WIP1 as a therapeutic strategy in cutaneous melanoma. Br. J. Cancer 2018, 118, 495-508. [CrossRef] [PubMed]

16. Jeay, S.; Gaulis, S.; Ferretti, S.; Bitter, H.; Ito, M.; Valat, T.; Murakami, M.; Ruetz, S.; Guthy, D.A.; Rynn, C.; et al. A distinct p53 target gene set predicts for response to the selective p53-HDM2 inhibitor NVP-CGM097. Elife 2015, 4, 1-23. [CrossRef] [PubMed]

17. Chang, B.D.; Xuan, Y.; Broude, E.V.; Zhu, H.; Schott, B.; Fang, J.; Roninson, I.B. Role of p53 and p21waf1/cip1 in senescence-like terminal proliferation arrest induced in human tumor cells by chemotherapeutic drugs. Oncogene 1999, 18, 4808-4818. [CrossRef]

18. Wu, X.; Bayle, J.H.; Olson, D.; Levine, A.J. The p53-mdm-2 autoregulatory feedback loop. Genes Dev. 1993, 7, 1126-1132. [CrossRef]

19. Batchelor, E.; Mock, C.S.; Bhan, I.; Loewer, A.; Lahav, G. Recurrent initiation: A mechanism for triggering p53 pulses in response to DNA damage. Mol. Cell 2008, 30, 277-289. [CrossRef]

20. Engeland, K. Cell cycle arrest through indirect transcriptional repression by p53: I have a DREAM. Cell Death Differ. 2018, 25, 114-132. [CrossRef]

21. Zhang, X.-P.; Liu, F.; Wang, W. Coordination between cell cycle progression and cell fate decision by the p53 and E2F1 pathways in response to DNA damage. J. Biol. Chem. 2010, 285, 31571-31580. [CrossRef] [PubMed]

22. Hat, B.; Kochańczyk, M.; Bogdał, M.N.; Lipniacki, T. Feedbacks, Bifurcations, and Cell Fate Decision-Making in the p53 System. PLoS Comput. Biol. 2016, 12, e1004787. [CrossRef] [PubMed]

23. Stambolic, V.; MacPherson, D.; Sas, D.; Lin, Y.; Snow, B.; Jang, Y.; Benchimol, S.; Mak, T.W. Regulation of PTEN transcription by p53. Mol. Cell 2001, 8, 317-325. [CrossRef]

24. Miyashita, T.; Reed, J.C. Tumor suppressor p53 is a direct transcriptional activator of the human bax gene. Cell 1995, 80, 293-299. [PubMed] 
25. Puca, R.; Nardinocchi, L.; Givol, D.; D'Orazi, G. Regulation of p53 activity by HIPK2: Molecular mechanisms and therapeutical implications in human cancer cells. Oncogene 2010, 29, 4378-4387. [CrossRef] [PubMed]

26. Zhang, X.; Liu, F.; Cheng, Z.; Wang, W. Cell fate decision mediated by p53 pulses. Proc. Natl. Acad. Sci. USA 2009, 106, 12245-12250. [CrossRef] [PubMed]

27. Zhang, X.-P.; Liu, F.; Wang, W. Two-phase dynamics of p53 in the DNA damage response. Proc. Natl. Acad. Sci. USA 2011, 108, 8990-8995. [CrossRef] [PubMed]

28. Kracikova, M.; Akiri, G.; George, A.; Sachidanandam, R.; Aaronson, S.A. A threshold mechanism mediates p53 cell fate decision between growth arrest and apoptosis. Cell Death Differ. 2013, 20, 576-588. [CrossRef]

29. Krenning, L.; Feringa, F.M.; Shaltiel, I.A.; van den Berg, J.; Medema, R.H. Transient activation of p53 in G2 phase is sufficient to induce senescence. Mol. Cell 2014, 55, 59-72. [CrossRef]

30. Tisato, V.; Voltan, R.; Gonelli, A.; Secchiero, P.; Zauli, G. MDM2/X inhibitors under clinical evaluation: Perspectives for the management of hematological malignancies and pediatric cancer. J. Hematol. Oncol. 2017, 10, 133. [CrossRef]

31. Skalniak, L.; Surmiak, E.; Holak, T.A. A therapeutic patent overview of MDM2/X-targeted therapies (2014-2018). Expert Opin. Ther. Pat. 2019, 29, 151-170. [CrossRef] [PubMed]

32. Reuther, C.; Heinzle, V.; Nölting, S.; Herterich, S.; Hahner, S.; Halilovic, E.; Jeay, S.; Wuerthner, J.U.; Aristizabal Prada, E.T.; Spöttl, G.; et al. The HDM2 (MDM2) Inhibitor NVP-CGM097 Inhibits Tumor Cell Proliferation and Shows Additive Effects with 5-Fluorouracil on the p53-p21-Rb-E2F1 Cascade in the p53 ${ }^{\text {wild type }}$ Neuroendocrine Tumor Cell Line GOT1. Neuroendocrinology 2018, 106, 1-19. [CrossRef]

33. Coll-Mulet, L.; Iglesias-Serret, D.; Santidrián, A.F.; Cosialls, A.M.; de Frias, M.; Castaño, E.; Campàs, C.; Barragán, M.; de Sevilla, A.F.; Domingo, A.; et al. MDM2 antagonists activate p53 and synergize with genotoxic drugs in B-cell chronic lymphocytic leukemia cells. Blood 2006, 107, 4109-4114. [CrossRef] [PubMed]

34. Chen, L.; Rousseau, R.F.; Middleton, S.A.; Nichols, G.L.; Newell, D.R.; Lunec, J.; Tweddle, D.A. Pre-clinical evaluation of the MDM2-p53 antagonist RG7388 alone and in combination with chemotherapy in neuroblastoma. Oncotarget 2015, 6, 10207-10221. [CrossRef] [PubMed]

35. Canon, J.; Osgood, T.; Olson, S.H.; Saiki, A.Y.; Robertson, R.; Yu, D.; Eksterowicz, J.; Ye, Q.; Jin, L.; Chen, A.; et al. The MDM2 Inhibitor AMG 232 Demonstrates Robust Antitumor Efficacy and Potentiates the Activity of p53-Inducing Cytotoxic Agents. Mol. Cancer Ther. 2015, 14, 649-658. [CrossRef] [PubMed]

36. Tonsing-Carter, E.; Bailey, B.J.; Saadatzadeh, M.R.; Ding, J.; Wang, H.; Sinn, A.L.; Peterman, K.M.; Spragins, T.K.; Silver, J.M.; Sprouse, A.A.; et al. Potentiation of Carboplatin-Mediated DNA Damage by the Mdm2 Modulator Nutlin-3a in a Humanized Orthotopic Breast-to-Lung Metastatic Model. Mol. Cancer Ther. 2015, 14, 2850-2863. [CrossRef] [PubMed]

37. Zanjirband, M.; Edmondson, R.J.; Lunec, J. Pre-clinical efficacy and synergistic potential of the MDM2-p53 antagonists, Nutlin-3 and RG7388, as single agents and in combined treatment with cisplatin in ovarian cancer. Oncotarget 2016, 7, 40115-40134. [CrossRef] [PubMed]

38. Azmi, A.S.; Aboukameel, A.; Banerjee, S.; Wang, Z.; Mohammad, M.; Wu, J.; Wang, S.; Yang, D.; Philip, P.A.; Sarkar, F.H.; et al. MDM2 inhibitor MI-319 in combination with cisplatin is an effective treatment for pancreatic cancer independent of p53 function. Eur. J. Cancer 2010, 46, 1122-1131. [CrossRef] [PubMed]

39. Voon, Y.-L.; Ahmad, M.; Wong, P.; Husaini, R.; Ng, W.T.; Leong, C.-O.; Lane, D.P.; Khoo, A.S.-B. Nutlin-3 sensitizes nasopharyngeal carcinoma cells to cisplatin-induced cytotoxicity. Oncol. Rep. 2015, 34, 1692-1700. [CrossRef]

40. Deben, C.; Wouters, A.; Op de Beeck, K.; van Den Bossche, J.; Jacobs, J.; Zwaenepoel, K.; Peeters, M.; Van Meerbeeck, J.; Lardon, F.; Rolfo, C.; et al. The MDM2-inhibitor Nutlin-3 synergizes with cisplatin to induce p53 dependent tumor cell apoptosis in non-small cell lung cancer. Oncotarget 2015, 6, 22666-22679. [CrossRef]

41. Carrillo, A.M.; Hicks, M.; Khabele, D.; Eischen, C.M. Pharmacologically Increasing Mdm2 Inhibits DNA Repair and Cooperates with Genotoxic Agents to Kill p53-Inactivated Ovarian Cancer Cells. Mol. Cancer Res. 2015, 13, 1197-1205. [CrossRef]

42. Ohnstad, H.O.; Paulsen, E.B.; Noordhuis, P.; Berg, M.; Lothe, R.A.; Vassilev, L.T.; Myklebost, O. MDM2 antagonist Nutlin-3a potentiates antitumour activity of cytotoxic drugs in sarcoma cell lines. BMC Cancer 2011, 11, 211. [CrossRef] 
43. Barbieri, E.; Mehta, P.; Chen, Z.; Zhang, L.; Slack, A.; Berg, S.; Shohet, J.M. MDM2 inhibition sensitizes neuroblastoma to chemotherapy-induced apoptotic cell death. Mol. Cancer Ther. 2006, 5, 2358-2365. [CrossRef]

44. Seipel, K.; Marques, M.A.T.; Sidler, C.; Mueller, B.U.; Pabst, T. MDM2- and FLT3-inhibitors in the treatment of FLT3 -ITD acute myeloid leukemia, specificity and efficacy of NVP-HDM201 and midostaurin. Haematologica 2018, 103, 1862-1872. [CrossRef]

45. Drakos, E.; Singh, R.R.; Rassidakis, G.Z.; Schlette, E.; Li, J.; Claret, F.X.; Ford, R.J.; Vega, F.; Medeiros, L.J. Activation of the p53 pathway by the MDM2 inhibitor nutlin-3a overcomes BCL2 overexpression in a preclinical model of diffuse large B-cell lymphoma associated with $\mathrm{t}(14 ; 18)$ (q32;q21). Leukemia 2011, 25, 856-867. [CrossRef]

46. Conradt, L.; Henrich, A.; Wirth, M.; Reichert, M.; Lesina, M.; Algül, H.; Schmid, R.M.; Krämer, O.H.; Saur, D.; Schneider, G. Mdm2 inhibitors synergize with topoisomerase II inhibitors to induce p53-independent pancreatic cancer cell death. Int. J. Cancer 2013, 132, 2248-2257. [CrossRef]

47. Zheng, M.; Yang, J.; Xu, X.; Sebolt, J.T.; Wang, S.; Sun, Y. Efficacy of MDM2 inhibitor MI-219 against lung cancer cells alone or in combination with MDM2 knockdown, a XIAP inhibitor or etoposide. Anticancer Res. 2010, 30, 3321-3331.

48. Kojima, K.; Konopleva, M.; McQueen, T.; Brien, S.O.; Plunkett, W.; Andreeff, M.; O’Brien, S.; Plunkett, W.; Andreeff, M. Mdm2 inhibitor Nutlin-3a induces p53-mediated apoptosis by transcription-dependent and transcription-independent mechanisms and may overcome Atm-mediated resistance to fludarabine in chronic lymphocytic leukemia. Blood 2006, 108, 993-1000. [CrossRef]

49. Jones, R.J.; Baladandayuthapani, V.; Neelapu, S.; Fayad, L.E.; Romaguera, J.E.; Wang, M.; Sharma, R.; Yang, D.; Orlowski, R.Z. HDM-2 inhibition suppresses expression of ribonucleotide reductase subunit M2, and synergistically enhances gemcitabine-induced cytotoxicity in mantle cell lymphoma. Blood 2011, 118, 4140-4149. [CrossRef]

50. Prabakaran, P.J.; Javaid, A.M.; Swick, A.D.; Werner, L.R.; Nickel, K.P.; Sampene, E.; Hu, R.; Ong, I.M.; Bruce, J.Y.; Hartig, G.K.; et al. Radiosensitization of Adenoid Cystic Carcinoma with MDM2 Inhibition. Clin. Cancer Res. 2017, 23, 6044-6053. [CrossRef]

51. Phelps, D.; Bondra, K.; Seum, S.; Chronowski, C.; Leasure, J.; Kurmasheva, R.T.; Middleton, S.; Wang, D.; Mo, X.; Houghton, P.J. Inhibition of MDM2 by RG7388 confers hypersensitivity to X-radiation in xenograft models of childhood sarcoma. Pediatr. Blood Cancer 2015, 62, 1345-1352. [CrossRef]

52. Arya, A.K.; El-Fert, A.; Devling, T.; Eccles, R.M.; Aslam, M.A.; Rubbi, C.P.; Vlatković, N.; Fenwick, J.; Lloyd, B.H.; Sibson, D.R.; et al. Nutlin-3, the small-molecule inhibitor of MDM2, promotes senescence and radiosensitises laryngeal carcinoma cells harbouring wild-type p53. Br. J. Cancer 2010, 103, 186-195. [CrossRef]

53. Villalonga-Planells, R.; Coll-Mulet, L.; Martínez-Soler, F.; Castaño, E.; Acebes, J.-J.; Giménez-Bonafé, P.; Gil, J.; Tortosa, A. Activation of p53 by nutlin-3a induces apoptosis and cellular senescence in human glioblastoma multiforme. PLoS ONE 2011, 6, e18588. [CrossRef]

54. Azmi, A.S.; Banerjee, S.; Ali, S.; Wang, Z.; Bao, B.; Beck, F.W.J.; Maitah, M.; Choi, M.; Shields, T.F.; Philip, P.A.; et al. Network modeling of MDM2 inhibitor-oxaliplatin combination reveals biological synergy in wt-p53 solid tumors. Oncotarget 2011, 2, 378-392. [CrossRef]

55. Chen, L.; Pastorino, F.; Berry, P.; Bonner, J.; Kirk, C.; Wood, K.M.; Thomas, H.D.; Zhao, Y.; Daga, A.; Veal, G.J.; et al. Preclinical evaluation of the first intravenous small molecule MDM2 antagonist alone and in combination with temozolomide in neuroblastoma. Int. J. Cancer 2019, 144, 3146-3159. [CrossRef]

56. Obrador-Hevia, A.; Martinez-Font, E.; Felipe-Abrio, I.; Calabuig-Fariñas, S.; Serra-Sitjar, M.; López-Guerrero, J.A.; Ramos, R.; Alemany, R.; Martín-Broto, J. RG7112, a small-molecule inhibitor of MDM2, enhances trabectedin response in soft tissue sarcomas. Cancer Invest. 2015, 33, 440-450. [CrossRef]

57. Stolte, B.; Iniguez, A.B.; Dharia, N.V.; Robichaud, A.L.; Conway, A.S.; Morgan, A.M.; Alexe, G.; Schauer, N.J.; Liu, X.; Bird, G.H.; et al. Genome-scale CRISPR-Cas9 screen identifies druggable dependencies in TP53 wild-type Ewing sarcoma. J. Exp. Med. 2018, 215, 2137-2155. [CrossRef]

58. Sriraman, A.; Radovanovic, M.; Wienken, M.; Najafova, Z.; Li, Y.; Dobbelstein, M. Cooperation of Nutlin-3a and a Wip1 inhibitor to induce p53 activity. Oncotarget 2016, 7, 31623-31638. [CrossRef] 
59. Zanjirband, M.; Curtin, N.; Edmondson, R.J.; Lunec, J. Combination treatment with rucaparib (Rubraca) and MDM2 inhibitors, Nutlin-3 and RG7388, has synergistic and dose reduction potential in ovarian cancer. Oncotarget 2017, 8, 69779-69796. [CrossRef]

60. Kojima, K.; Konopleva, M.; Samudio, I.J.; Schober, W.D.; Bornmann, W.G.; Andreeff, M. Concomitant inhibition of MDM2 and Bcl-2 protein function synergistically induce mitochondrial apoptosis in AML. Cell Cycle 2006, 5, 2778-2786. [CrossRef]

61. Carter, B.Z.; Mak, P.Y.; Mak, D.H.; Ruvolo, V.R.; Schober, W.; McQueen, T.; Cortes, J.; Kantarjian, H.M.; Champlin, R.E.; Konopleva, M.; et al. Synergistic effects of p53 activation via MDM2 inhibition in combination with inhibition of $\mathrm{Bcl}-2$ or Bcr-Abl in $\mathrm{CD} 34^{+}$proliferating and quiescent chronic myeloid leukemia blast crisis cells. Oncotarget 2015, 6, 30487-30499. [CrossRef]

62. Gu, D.; Wang, S.; Kuiatse, I.; Wang, H.; He, J.; Dai, Y.; Jones, R.J.; Bjorklund, C.C.; Yang, J.; Grant, S.; et al. Inhibition of the MDM2 E3 Ligase induces apoptosis and autophagy in wild-type and mutant p53 models of multiple myeloma, and acts synergistically with ABT-737. PLoS ONE 2014, 9, e103015. [CrossRef]

63. Wang, X.-H.; Zhang, S.-F.; Bao, J.-T.; Liu, F.-Y. Oridonin synergizes with Nutlin-3 in osteosarcoma cells by modulating the levels of multiple Bcl-2 family proteins. Tumour Biol. 2017, 39, 1010428317701638. [CrossRef]

64. Lehmann, C.; Friess, T.; Birzele, F.; Kiialainen, A.; Dangl, M. Superior anti-tumor activity of the MDM2 antagonist idasanutlin and the Bcl-2 inhibitor venetoclax in p53 wild-type acute myeloid leukemia models. J. Hematol. Oncol. 2016, 9, 50. [CrossRef]

65. Van Goethem, A.; Yigit, N.; Moreno-Smith, M.; Vasudevan, S.A.; Barbieri, E.; Speleman, F.; Shohet, J.; Vandesompele, J.; Van Maerken, T. Dual targeting of MDM2 and BCL2 as a therapeutic strategy in neuroblastoma. Oncotarget 2017, 8, 57047-57057. [CrossRef]

66. Carter, B.Z.; Mak, D.H.; Schober, W.D.; Koller, E.; Pinilla, C.; Vassilev, L.T.; Reed, J.C.; Andreeff, M. Simultaneous activation of p53 and inhibition of XIAP enhance the activation of apoptosis signaling pathways in AML. Blood 2010, 115, 306-314. [CrossRef]

67. Meijer, A.; Kruyt, F.A.E.; Van Der Zee, A.G.J.; Hollema, H.; Le, P.; Ten Hoor, K.A.; Groothuis, G.M.M.; Quax, W.J.; De Vries, E.G.E.; De Jong, S. Nutlin-3 preferentially sensitises wild-type p53-expressing cancer cells to DR5-selective TRAIL over rhTRAIL. Br. J. Cancer 2013, 109, 2685-2695. [CrossRef]

68. Urso, L.; Cavallari, I.; Silic-Benussi, M.; Biasini, L.; Zago, G.; Calabrese, F.; Conte, P.F.; Ciminale, V.; Pasello, G. Synergistic targeting of malignant pleural mesothelioma cells by MDM2 inhibitors and TRAIL agonists. Oncotarget 2017, 8, 44232-44241. [CrossRef]

69. Wang, H.Q.; Halilovic, E.; Li, X.; Liang, J.; Cao, Y.; Rakiec, D.P.; Ruddy, D.A.; Jeay, S.; Wuerthner, J.U.; Timple, N.; et al. Combined ALK and MDM2 inhibition increases antitumor activity and overcomes resistance in human ALK mutant neuroblastoma cell lines and xenograft models. Elife 2017, 6, 1-19. [CrossRef]

70. Zauli, G.; Voltan, R.; Bosco, R.; Melloni, E.; Marmiroli, S.; Rigolin, G.M.; Cuneo, A.; Secchiero, P. Dasatinib plus nutlin-3 shows synergistic antileukemic activity in both p53wild-typeand p53mutated B chronic lymphocytic leukemias by inhibiting the Akt pathway. Clin. Cancer Res. 2011, 17, 762-770. [CrossRef]

71. Trino, S.; Iacobucci, I.; Erriquez, D.; Laurenzana, I.; De Luca, L.; Ferrari, A.; Di Rorà, A.G.L.; Papayannidis, C.; Derenzini, E.; Simonetti, G.; et al. Targeting the p53-MDM2 interaction by the small-molecule MDM2 antagonist Nutlin-3a: A new challenged target therapy in adult Philadelphia positive acute lymphoblastic leukemia patients. Oncotarget 2016, 7, 12951-12961. [CrossRef]

72. Voltan, R.; Rimondi, E.; Melloni, E.; Rigolin, G.M.; Casciano, F.; Arcidiacono, M.V.; Celeghini, C.; Cuneo, A.; Zauli, G.; Secchiero, P. Ibrutinib synergizes with MDM-2 inhibitors in promoting cytotoxicity in B chronic lymphocytic leukemia. Oncotarget 2016, 7, 70623-70638. [CrossRef]

73. Weisberg, E.; Halilovic, E.; Cooke, V.G.; Nonami, A.; Ren, T.; Sanda, T.; Simkin, I.; Yuan, J.; Antonakos, B.; Barys, L.; et al. Inhibition of Wild-Type p53-Expressing AML by the Novel Small Molecule HDM2 Inhibitor CGM097. Mol. Cancer Ther. 2015, 14, 2249-2259. [CrossRef]

74. Zauli, G.; Celeghini, C.; Melloni, E.; Voltan, R.; Ongari, M.; Tiribelli, M.; di Iasio, M.G.; Lanza, F.; Secchiero, P. The sorafenib plus nutlin-3 combination promotes synergistic cytotoxicity in acute myeloid leukemic cells irrespectively of FLT3 and p53 status. Haematologica 2012, 97, 1722-1730. [CrossRef]

75. Vatsyayan, R.; Singhal, J.; Nagaprashantha, L.D.; Awasthi, S.; Singhal, S.S. Nutlin-3 enhances sorafenib efficacy in renal cell carcinoma. Mol. Carcinog. 2013, 52, 39-48. [CrossRef] 
76. McIntosh, J.; Huang, X.; Yan, X.; Lo, M.-C.; Ye, Q.; Houze, J.B.; Mihalic, J.; Oliner, J.D.; Medina, J.C.; Yu, M.; et al. Discovery of AMG 232, a Potent, Selective, and Orally Bioavailable MDM2-p53 Inhibitor in Clinical Development. J. Med. Chem. 2014, 57, 1454-1472.

77. Zhang, W.; Konopleva, M.; Burks, J.K.; Dywer, K.C.; Schober, W.D.; Yang, J.-Y.; McQueen, T.J.; Hung, M.-C.; Andreeff, M. Blockade of MEK and MDM2 synergistically induces apoptosis in acute myeloid leukemia via BH3-only proteins Puma and Bim. Cancer Res. 2010, 70, 2424-2434. [CrossRef]

78. Moschos, S.J.; Sandhu, S.K.; Lewis, K.D.; Sullivan, R.J.; Johnson, D.B.; Zhang, Y.; Rasmussen, E.; Henary, H.A.; Long, G.V. Phase 1 study of the p53-MDM2 inhibitor AMG 232 combined with trametinib plus dabrafenib or trametinib in patients (Pts) with TP53 wild type (TP53WT) metastatic cutaneous melanoma (MCM). J. Clin. Oncol. 2017, 35, 2575. [CrossRef]

79. Saiki, A.Y.; Caenepeel, S.; Yu, D.; Lofgren, J.A.; Osgood, T.; Robertson, R.; Canon, J.; Su, C.; Jones, A.; Zhao, X.; et al. MDM2 antagonists synergize broadly and robustly with compounds targeting fundamental oncogenic signaling pathways. Oncotarget 2014, 5, 2030-2043. [CrossRef]

80. Wang, H.Q.; Zubrowski, M.; Emerson, E.; Pradhan, E.; Jeay, S.; Wiesmann, M.; Caponigro, G.; Wuerthner, J.; Schlegel, R.; Cao, Z.A.; et al. Abstract 5466: The Mdm2 inhibitor, NVP-CGM097, in combination with the BRAF inhibitor NVP-LGX818 elicits synergistic antitumor effects in melanoma. In Proceedings of the 2014 Annual Meeting of the American Association for Cancer Research, Experimental and Molecular Therapeutics, San Diego, CA, USA, 5-9 April 2014; Volume 74, p. 5466.

81. de Weger, V.A.; de Jonge, M.; Langenberg, M.H.G.G.; Schellens, J.H.M.M.; Lolkema, M.; Varga, A.; Demers, B.; Thomas, K.; Hsu, K.; Tuffal, G.; et al. A phase I study of the HDM2 antagonist SAR405838 combined with the MEK inhibitor pimasertib in patients with advanced solid tumours. Br. J. Cancer 2019, 120, 286-293. [CrossRef]

82. Wu, C.-E.; Koay, T.S.; Esfandiari, A.; Ho, Y.-H.; Lovat, P.; Lunec, J. ATM Dependent DUSP6 Modulation of p53 Involved in Synergistic Targeting of MAPK and p53 Pathways with Trametinib and MDM2 Inhibitors in Cutaneous Melanoma. Cancers 2018, 11, 3. [CrossRef]

83. Laroche, A.; Chaire, V.; Algeo, M.-P.; Karanian, M.; Fourneaux, B.; Italiano, A. MDM2 antagonists synergize with PI3K/mTOR inhibition in well-differentiated/dedifferentiated liposarcomas. Oncotarget 2017, 8, 53968-53977. [CrossRef]

84. Zhu, N.; Gu, L.; Li, F.; Zhou, M. Inhibition of the Akt/survivin pathway synergizes the antileukemia effect of nutlin-3 in acute lymphoblastic leukemia cells. Mol. Cancer Ther. 2008, 7, 1101-1109. [CrossRef]

85. Kojima, K.; Shimanuki, M.; Shikami, M.; Samudio, I.J.; Ruvolo, V.; Corn, P.; Hanaoka, N.; Konopleva, M.; Andreeff, M.; Nakakuma, H. The dual PI3 kinase/mTOR inhibitor PI-103 prevents p53 induction by Mdm2 inhibition but enhances p53-mediated mitochondrial apoptosis in p53 wild-type AML. Leukemia 2008, 22, 1728-1736. [CrossRef]

86. Schmeits, P.C.J.; Hermans, M.H.A.; Van Geest-daalderop, J.H.H.; Poodt, J.; Nolting, P.R.W.D.S.; Conemans, J.M.H. Perifosine plus nutlin-3 combination shows a synergistic anti-leukaemic activity. Br. J. Haematol. 2009, 3, 957-961.

87. Sriraman, A.; Dickmanns, A.; Najafova, Z.; Johnsen, S.A.; Dobbelstein, M. CDK4 inhibition diminishes p53 activation by MDM2 antagonists. Cell Death Dis. 2018, 9, 918. [CrossRef]

88. Laroche-Clary, A.; Chaire, V.; Algeo, M.-P.; Derieppe, M.-A.; Loarer, F.L.; Italiano, A. Combined targeting of MDM2 and CDK4 is synergistic in dedifferentiated liposarcomas. J. Hematol. Oncol. 2017, 10, 123. [CrossRef]

89. Ribas, J.; Boix, J.; Meijer, L. (R)-roscovitine (CYC202, Seliciclib) sensitizes SH-SY5Y neuroblastoma cells to nutlin-3-induced apoptosis. Exp. Cell Res. 2006, 312, 2394-2400. [CrossRef]

90. Cheok, C.F.; Dey, A.; Lane, D.P. Cyclin-dependent kinase inhibitors sensitize tumor cells to nutlin-induced apoptosis: A potent drug combination. Mol. Cancer Res. 2007, 5, 1133-1145. [CrossRef]

91. Carita, G.; Frisch-Dit-Leitz, E.; Dahmani, A.; Raymondie, C.; Cassoux, N.; Piperno-Neumann, S.; Némati, F.; Laurent, C.; De Koning, L.; Halilovic, E.; et al. Dual inhibition of protein kinase C and p53-MDM2 or PKC and mTORC1 are novel efficient therapeutic approaches for uveal melanoma. Oncotarget 2016, 7, 33542-33556. [CrossRef]

92. Jak, M.; Reits, E.A.; Kallemeijn, W.W.; Tromp, J.M.; Klein, C.; Eldering, E. CD40 stimulation sensitizes CLL cells to lysosomal cell death induction by type II anti-CD20 monoclonal antibody GA101. Blood 2011, 118, 5178-5189. [CrossRef] 
93. Herting, F.; Herter, S.; Friess, T.; Muth, G.; Bacac, M.; Sulcova, J.; Umana, P.; Dangl, M.; Klein, C. Antitumour activity of the glycoengineered type II anti-CD20 antibody obinutuzumab (GA101) in combination with the MDM2-selective antagonist idasanutlin (RG7388). Eur. J. Haematol. 2016, 97, 461-470. [CrossRef]

94. Pishas, K.I.; Neuhaus, S.J.; Clayer, M.T.; Adwal, A.; Brown, M.P.; Evdokiou, A.; Callen, D.F.; Neilsen, P.M. Pre-activation of the p53 pathway through Nutlin-3a sensitises sarcomas to drozitumab therapy. Oncol. Rep. 2013, 30, 471-477. [CrossRef]

95. Ooi, M.G.; Hayden, P.J.; Kotoula, V.; McMillin, D.W.; Charalambous, E.; Daskalaki, E.; Raje, N.S.; Munshi, N.C.; Chauhan, D.; Hideshima, T.; et al. Interactions of the Hdm2/p53 and proteasome pathways may enhance the antitumor activity of bortezomib. Clin. Cancer Res. 2009, 15, 7153-7160. [CrossRef]

96. Saha, M.N.; Jiang, H.; Jayakar, J.; Reece, D.; Branch, D.R.; Chang, H. MDM2 antagonist nutlin plus proteasome inhibitor velcade combination displays a synergistic anti-myeloma activity. Cancer Biol. Ther. 2010, 9, 936-944. [CrossRef]

97. Tabe, Y.; Sebasigari, D.; Jin, L.; Rudelius, M.; Davies-Hill, T.; Miyake, K.; Miida, T.; Pittaluga, S.; Raffeld, M. MDM2 antagonist nutlin-3 displays antiproliferative and proapoptotic activity in mantle cell lymphoma. Clin. Cancer Res. 2009, 15, 933-942. [CrossRef]

98. Chen, H.; Xue, L.; Huang, H.; Wang, H.; Zhang, X.; Zhu, W.; Wang, Z.; Wang, Z.; Wu, H. Synergistic effect of Nutlin-3 combined with MG-132 on schwannoma cells through restoration of merlin and p53 tumour suppressors. EBioMedicine 2018, 36, 252-265. [CrossRef]

99. Borthakur, G.; Duvvuri, S.; Samudio, I.J.; Kojima, K.; Konopleva, M.; Andreeff, M. Synergistic Activation of p53 Family of Proteins by the Combination of Nutlin 3a and SAHA in Acute Myelogenous Leukemia. Blood 2009, 114, 1738.

100. McCormack, E.; Haaland, I.; Venås, G.; Forthun, R.B.; Huseby, S.; Gausdal, G.; Knappskog, S.; Micklem, D.R.; Lorens, J.B.; Bruserud, O.; et al. Synergistic induction of p53 mediated apoptosis by valproic acid and nutlin-3 in acute myeloid leukemia. Leukemia 2012, 26, 910-917. [CrossRef]

101. Miyachi, M.; Kakazu, N.; Yagyu, S.; Katsumi, Y.; Tsubai-Shimizu, S.; Kikuchi, K.; Tsuchiya, K.; Iehara, T.; Hosoi, H. Restoration of p53 pathway by nutlin-3 induces cell cycle arrest and apoptosis in human rhabdomyosarcoma cells. Clin. Cancer Res. 2009, 15, 4077-4084. [CrossRef]

102. Zajkowicz, A.; Gdowicz-Kłosok, A.; Krześniak, M.; Ścieglińska, D.; Rusin, M. Actinomycin D and nutlin-3a synergistically promote phosphorylation of p53 on serine 46 in cancer cell lines of different origin. Cell. Signal. 2015, 27, 1677-1687. [CrossRef]

103. Zaman, S.; Yu, X.; Bencivenga, A.F.; Blanden, A.R.; Liu, Y.; Withers, T.; Na, B.; Blayney, A.J.; Gilleran, J.; Boothman, D.A.; et al. Combinatorial therapy of Zinc metallochaperones with mutant $\mathrm{p} 53$ reactivation and diminished copper binding. Mol. Cancer Ther. 2019. [CrossRef]

104. Haaland, I.; Opsahl, J.A.; Berven, F.S.; Reikvam, H.; Fredly, H.K.; Haugse, R.; Thiede, B.; McCormack, E.; Lain, S.; Bruserud, O.; et al. Molecular mechanisms of nutlin-3 involve acetylation of p53, histones and heat shock proteins in acute myeloid leukemia. Mol. Cancer 2014, 13, 116. [CrossRef]

105. Schneider, L.S.; Ulrich, M.; Lehr, T.; Menche, D.; Müller, R.; von Schwarzenberg, K. MDM2 antagonist nutlin-3a sensitizes tumors to V-ATPase inhibition. Mol. Oncol. 2016, 10, 1054-1062. [CrossRef]

106. Richmond, J.; Carol, H.; Evans, K.; High, L.; Mendomo, A.; Robbins, A.; Meyer, C.; Venn, N.C.; Marschalek, R.; Henderson, M.; et al. Effective targeting of the P53-MDM2 axis in preclinical models of infant MLL-rearranged acute lymphoblastic leukemia. Clin. Cancer Res. 2015, 21, 1395-1405. [CrossRef]

107. Shimazu, K.; Tada, Y.; Morinaga, T.; Shingyoji, M.; Sekine, I.; Shimada, H.; Hiroshima, K.; Namiki, T.; Tatsumi, K.; Tagawa, M. Metformin produces growth inhibitory effects in combination with nutlin-3a on malignant mesothelioma through a cross-talk between mTOR and p53 pathways. BMC Cancer 2017, 17, 309. [CrossRef]

108. Guo, Y.; Li, Y.; Wang, F.-F.; Xiang, B.; Huang, X.-O.; Ma, H.-B.; Gong, Y.-P. The combination of Nutlin-3 and Tanshinone IIA promotes synergistic cytotoxicity in acute leukemic cells expressing wild-type p53 by co-regulating MDM2-P53 and the AKT/mTOR pathway. Int. J. Biochem. Cell Biol. 2019, 106, 8-20. [CrossRef]

109. Nguyen, D.; Liao, W.; Zeng, S.X.; Lu, H. Reviving the guardian of the genome: Small molecule activators of p53. Pharmacol. Ther. 2017, 178, 92-108. [CrossRef] 
110. Zhao, Y.; Aguilar, A.; Bernard, D.; Wang, S. Small-molecule inhibitors of the MDM2-p53 protein-protein interaction (MDM2 Inhibitors) in clinical trials for cancer treatment. J. Med. Chem. 2015, 58, 1038-1052. [CrossRef]

111. Kussie, P.H.; Gorina, S.; Marechal, V.; Elenbaas, B.; Moreau, J.; Levine, A.J.; Pavletich, N.P. Structure of the MDM2 oncoprotein bound to the p53 tumor suppressor transactivation domain. Science 1996, 274, 948-953. [CrossRef]

112. Estrada-Ortiz, N.; Neochoritis, C.G.; Dömling, A. How to Design a Successful p53-MDM2/X Interaction Inhibitor: A Thorough Overview Based on Crystal Structures. ChemMedChem 2016, 11, 757-772. [CrossRef]

113. Vassilev, L.T.; Vu, B.T.; Graves, B.; Carvajal, D.; Podlaski, F.; Filipovic, Z.; Kong, N.; Kammlott, U.; Lukacs, C.; Klein, C.; et al. In vivo activation of the 553 pathway by small-molecule antagonists of MDM2. Science 2004, 303, 844-848. [CrossRef]

114. Vu, B.; Wovkulich, P.; Pizzolato, G.; Lovey, A.; Ding, Q.; Jiang, N.; Liu, J.-J.; Zhao, C.; Glenn, K.; Wen, Y.; et al. Discovery of RG7112: A Small-Molecule MDM2 Inhibitor in Clinical Development. ACS Med. Chem. Lett. 2013, 4, 466-469. [CrossRef]

115. Ding, Q.; Zhang, Z.; Liu, J.; Jiang, N.; Zhang, J.; Ross, T.M.; Chu, X.; Bartkovitz, D.; Podlaski, F.; Janson, C.; et al. Discovery of RG7388, a potent and selective p53-MDM2 inhibitor in clinical development. J. Med. Chem. 2013, 56, 5979-5983. [CrossRef]

116. Ding, K.; Lu, Y.; Nikolovska-Coleska, Z.; Wang, G.; Qiu, S.; Shangary, S.; Gao, W.; Qin, D.; Stuckey, J.; Krajewski, K.; et al. Structure-based design of spiro-oxindoles as potent, specific small-molecule inhibitors of the MDM2-p53 interaction. J. Med. Chem. 2006, 49, 3432-3435. [CrossRef]

117. Shangary, S.; Qin, D.; McEachern, D.; Liu, M.; Miller, R.S.; Qiu, S.; Nikolovska-Coleska, Z.; Ding, K.; Wang, G.; Chen, J.; et al. Temporal activation of p53 by a specific MDM2 inhibitor is selectively toxic to tumors and leads to complete tumor growth inhibition. Proc. Natl. Acad. Sci. USA. 2008, 105, 3933-3938. [CrossRef]

118. Canner, J.A.; Sobo, M.; Ball, S.; Hutzen, B.; DeAngelis, S.; Willis, W.; Studebaker, A.W.; Ding, K.; Wang, S.; Yang, D.; et al. MI-63: A novel small-molecule inhibitor targets MDM2 and induces apoptosis in embryonal and alveolar rhabdomyosarcoma cells with wild-type p53. Br. J. Cancer 2009, 101, 774-781. [CrossRef]

119. Wang, S.; Sun, W.; Zhao, Y.; McEachern, D.; Meaux, I.; Barrière, C.; Stuckey, J.A.; Meagher, J.L.; Bai, L.; Liu, L.; et al. SAR405838: An optimized inhibitor of MDM2-p53 interaction that induces complete and durable tumor regression. Cancer Res. 2014, 74, 5855-5865. [CrossRef]

120. Aguilar, A.; Lu, J.; Liu, L.; Du, D.; Bernard, D.; McEachern, D.; Przybranowski, S.; Li, X.; Luo, R.; Wen, B.; et al. Discovery of

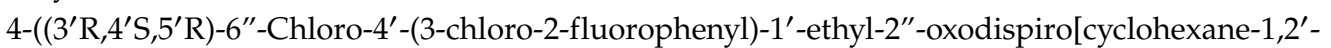
pyrrolidine-3', $3^{\prime \prime}$-indoline]-5'-carboxamido)bicyclo[2.2.2] octane-1-carboxylic Acid (AA-115/APG-115): A Potent and Orally Active Murine Double Minut. J. Med. Chem. 2017, 60, 2819-2839. [CrossRef]

121. Arnhold, V.; Schmelz, K.; Proba, J.; Winkler, A.; Wünschel, J.; Toedling, J.; Deubzer, H.E.; Künkele, A.; Eggert, A.; Schulte, J.H.; et al. Reactivating TP53 signaling by the novel MDM2 inhibitor DS-3032b as a therapeutic option for high-risk neuroblastoma. Oncotarget 2018, 9, 2304-2319. [CrossRef]

122. Furet, P.; Chène, P.; De Pover, A.; Valat, T.S.; Lisztwan, J.H.; Kallen, J.; Masuya, K. The central valine concept provides an entry in a new class of non peptide inhibitors of the p53-MDM2 interaction. Bioorg. Med. Chem. Lett. 2012, 22, 3498-3502. [CrossRef]

123. Holzer, P.; Masuya, K.; Furet, P.; Kallen, J.; Valat-Stachyra, T.; Ferretti, S.; Berghausen, J.; Bouisset-Leonard, M.; Buschmann, N.; Pissot-Soldermann, C.; et al. Discovery of a Dihydroisoquinolinone Derivative (NVP-CGM097): A Highly Potent and Selective MDM2 Inhibitor Undergoing Phase 1 Clinical Trials in p53wt Tumors. J. Med. Chem. 2015, 58, 6348-6358. [CrossRef]

124. Furet, P.; Masuya, K.; Kallen, J.; Stachyra-Valat, T.; Ruetz, S.; Guagnano, V.; Holzer, P.; Mah, R.; Stutz, S.; Vaupel, A.; et al. Discovery of a novel class of highly potent inhibitors of the p53-MDM2 interaction by structure-based design starting from a conformational argument. Bioorg. Med. Chem. Lett. 2016, 26, 4837-4841. [CrossRef]

125. Swift, L.H.; Golsteyn, R.M. Genotoxic anti-cancer agents and their relationship to DNA damage, mitosis, and checkpoint adaptation in proliferating cancer cells. Int. J. Mol. Sci. 2014, 15, 3403-3431. [CrossRef]

126. Kelland, L. The resurgence of platinum-based cancer chemotherapy. Nat. Rev. Cancer 2007, 7, 573-584. [CrossRef] 
127. Dasari, S.; Tchounwou, P.B. Cisplatin in cancer therapy: Molecular mechanisms of action. Eur. J. Pharmacol. 2014, 740, 364-378. [CrossRef]

128. Astolfi, L.; Ghiselli, S.; Guaran, V.; Chicca, M.; Simoni, E.; Olivetto, E.; Lelli, G.; Martini, A. Correlation of adverse effects of cisplatin administration in patients affected by solid tumours: A retrospective evaluation. Oncol. Rep. 2013, 29, 1285-1292. [CrossRef]

129. Helleday, T.; Petermann, E.; Lundin, C.; Hodgson, B.; Sharma, R.A. DNA repair pathways as targets for cancer therapy. Nat. Rev. Cancer 2008, 8, 193-204. [CrossRef]

130. Champoux, J.J. DNA topoisomerases: Structure, function, and mechanism. Annu. Rev. Biochem. 2001, 70, 369-413. [CrossRef]

131. Froelich-Ammon, S.J.; Osheroff, N. Topoisomerase poisons: Harnessing the dark side of enzyme mechanism. J. Biol. Chem. 1995, 270, 21429-21432. [CrossRef]

132. Baskar, R.; Lee, K.A.; Yeo, R.; Yeoh, K.-W. Cancer and radiation therapy: Current advances and future directions. Int. J. Med. Sci. 2012, 9, 193-199. [CrossRef]

133. Gianfaldoni, S.; Gianfaldoni, R.; Wollina, U.; Lotti, J.; Tchernev, G.; Lotti, T. An Overview on Radiotherapy: From Its History to Its Current Applications in Dermatology. Open Access Maced. J. Med. Sci. 2017, 5, 521-525. [CrossRef]

134. Jackson, S.P.; Bartek, J. The DNA-damage response in human biology and disease. Nature 2009, 461, 1071-1078. [CrossRef]

135. Berkey, F.J. Managing the adverse effects of radiation therapy. Am. Fam. Physician 2010, 82, 381-388, 394.

136. Perry, M.E.; Piette, J.; Zawadzki, J.A.; Harvey, D.; Levine, A.J. The mdm-2 gene is induced in response to UV light in a p53-dependent manner. Proc. Natl. Acad. Sci. USA 2006, 90, 11623-11627. [CrossRef]

137. Cao, C.; Shinohara, E.T.; Subhawong, T.K.; Geng, L.; Kim, K.W.; Albert, J.M.; Hallahan, D.E.; Lu, B. Radiosensitization of lung cancer by nutlin, an inhibitor of murine double minute 2. Mol. Cancer Ther. 2006, 5, 411-417. [CrossRef]

138. Yi, H.; Yan, X.; Luo, Q.; Yuan, L.; Li, B.; Pan, W.; Zhang, L.; Chen, H.; Wang, J.; Zhang, Y.; et al. A novel small molecule inhibitor of MDM2-p53 (APG-115) enhances radiosensitivity of gastric adenocarcinoma. J. Exp. Clin. Cancer Res. 2018, 37, 97. [CrossRef]

139. Tangutoori, S.; Baldwin, P.; Sridhar, S. PARP inhibitors: A new era of targeted therapy. Maturitas 2015, 81, 5-9. [CrossRef]

140. Shirley, M. Rucaparib: A Review in Ovarian Cancer. Target Oncol. 2019, 14, 237-246. [CrossRef]

141. Pecháčková, S.; Burdová, K.; Macurek, L. WIP1 phosphatase as pharmacological target in cancer therapy. J. Mol. Med. 2017, 95, 589-599. [CrossRef]

142. Richter, M.; Dayaram, T.; Gilmartin, A.G.; Ganji, G.; Pemmasani, S.K.; Van Der Key, H.; Shohet, J.M.; Donehower, L.A.; Kumar, R. WIP1 phosphatase as a potential therapeutic target in neuroblastoma. PLoS ONE 2015, 10, 1-15. [CrossRef]

143. Chen, J. The Cell-Cycle Arrest and Apoptotic Functions of p53 in Tumor Initiation and Progression. Cold Spring Harb. Perspect. Med. 2016, 6, a026104. [CrossRef]

144. Cory, S.; Huang, D.C.S.; Adams, J.M. The Bcl-2 family: Roles in cell survival and oncogenesis. Oncogene 2003, 22, 8590-8607. [CrossRef]

145. Xu, X.; Lai, Y.; Hua, Z.-C. Apoptosis and apoptotic body: Disease message and therapeutic target potentials. Biosci. Rep. 2019, 39, BSR20180992. [CrossRef]

146. Labi, V.; Erlacher, M. How cell death shapes cancer. Cell Death Dis. 2015, 6, e1675. [CrossRef]

147. Cang, S.; Iragavarapu, C.; Savooji, J.; Song, Y.; Liu, D. ABT-199 (venetoclax) and BCL-2 inhibitors in clinical development. J. Hematol. Oncol. 2015, 8, 1-8. [CrossRef]

148. Niu, X.; Wang, G.; Wang, Y.; Caldwell, J.T.; Edwards, H.; Xie, C.; Taub, J.W.; Li, C.; Lin, H.; Ge, Y. Acute myeloid leukemia cells harboring MLL fusion genes or with the acute promyelocytic leukemia phenotype are sensitive to the Bcl-2-selective inhibitor ABT-199. Leukemia 2014, 28, 1557-1560. [CrossRef]

149. Souers, A.J.; Leverson, J.D.; Boghaert, E.R.; Ackler, S.L.; Catron, N.D.; Chen, J.; Dayton, B.D.; Ding, H.; Enschede, S.H.; Fairbrother, W.J.; et al. ABT-199, a potent and selective BCL-2 inhibitor, achieves antitumor activity while sparing platelets. Nat. Med. 2013, 19, 202-208. [CrossRef]

150. Hatzivassiliou, G.; Haling, J.R.; Chen, H.; Song, K.; Price, S.; Heald, R.; Hewitt, J.F.M.; Zak, M.; Peck, A.; Orr, C.; et al. Mechanism of MEK inhibition determines efficacy in mutant KRAS-versus BRAF-driven cancers. Nature 2013, 501, 232-236. [CrossRef] 
151. van Delft, M.F.; Wei, A.H.; Mason, K.D.; Vandenberg, C.J.; Chen, L.; Czabotar, P.E.; Willis, S.N.; Scott, C.L.; Day, C.L.; Cory, S.; et al. The BH3 mimetic ABT-737 targets selective Bcl-2 proteins and efficiently induces apoptosis via Bak/Bax if Mcl-1 is neutralized. Cancer Cell 2006, 10, 389-399. [CrossRef]

152. Oltersdorf, T.; Elmore, S.W.; Shoemaker, A.R.; Armstrong, R.C.; Augeri, D.J.; Belli, B.A.; Bruncko, M.; Deckwerth, T.L.; Dinges, J.; Hajduk, P.J.; et al. An inhibitor of Bcl-2 family proteins induces regression of solid tumours. Nature 2005, 435, 677-681. [CrossRef]

153. Verstovsek, S.; Golemovic, M.; Kantarjian, H.; Manshouri, T.; Estrov, Z.; Manley, P.; Sun, T.; Arlinghaus, R.B.; Alland, L.; Dugan, M.; et al. AMN107, a novel aminopyrimidine inhibitor of p190 Bcr-Abl activation and of in vitro proliferation of Philadelphia-positive acute lymphoblastic leukemia cells. Cancer 2005, 104, 1230-1236. [CrossRef] 
154. Golemovic, M.; Giles, F.; Cortes, J.; Manshouri, T.; Manley, P.W.; Dugan, M.; Alland, L.; Griffin, J.D.; Arlinghaus, R.B.; Sun, T.; et al. Cancer Therapy: Preclinical AMN107, a Novel Aminopyrimidine Inhibitor of Bcr-Abl, Has In vitro Activity against Imatinib-Resistant Chronic Myeloid Leukemia. Clin. Cancer Res. 2005, 11, 4941-4947. [CrossRef]

155. Gu, Z.; Wang, X.; Qi, R.; Wei, L.; Huo, Y.; Ma, Y.; Shi, L.; Chang, Y.; Li, G.; Zhou, L. Oridonin induces apoptosis in uveal melanoma cells by upregulation of Bim and downregulation of Fatty Acid Synthase. Biochem. Biophys. Res. Commun. 2015, 457, 187-193. [CrossRef]

156. Weng, H.; Huang, H.; Dong, B.; Zhao, P.; Zhou, H.; Qu, L. Inhibition of miR-17 and miR-20a by oridonin triggers apoptosis and reverses chemoresistance by derepressing BIM-S. Cancer Res. 2014, 74, 4409-4419. [CrossRef]

157. Du, C.; Fang, M.; Li, Y.; Li, L.; Wang, X. Smac, a Mitochondrial Protein that Promotes Cytochrome c-Dependent Caspase Activationby Eliminating IAP Inhibition. Cell 2000, 102, 33-42. [CrossRef]

158. Eckelman, B.P.; Salvesen, G.S.; Scott, F.L. Human inhibitor of apoptosis proteins: Why XIAP is the black sheep of the family. EMBO Rep. 2006, 7, 988-994. [CrossRef]

159. Riley, M.F.; Lozano, G. The Many Faces of MDM2 Binding Partners. Genes Cancer 2012, 3, $226-239$. [CrossRef]

160. Wiley, S.R.; Schooley, K.; Smolak, P.J.; Din, W.S.; Huang, C.P.; Nicholl, J.K.; Sutherland, G.R.; Smith, T.D.; Rauch, C.; Smith, C.A.; et al. Identification and characterization of a new member of the TNF family that induces apoptosis. Immunity 1995, 3, 673-682. [CrossRef]

161. Kimberley, F.C.; Screaton, G.R. Following a TRAIL: Update on a ligand and its five receptors. Cell Res. 2004, 14, 359-372. [CrossRef]

162. De Miguel, D.; Lemke, J.; Anel, A.; Walczak, H.; Martinez-Lostao, L. Onto better TRAILs for cancer treatment. Cell Death Differ. 2016, 23, 733-747. [CrossRef]

163. Merino, D.; Lalaoui, N.; Morizot, A.; Schneider, P.; Solary, E.; Micheau, O. Differential Inhibition of TRAIL-Mediated DR5-DISC Formation by Decoy Receptors 1 and 2. Mol. Cell. Biol. 2006, 26, 7046-7055. [CrossRef]

164. Chaudhary, P.M.; Eby, M.; Jasmin, A.; Bookwalter, A.; Murray, J.; Hood, L. Death receptor 5, a new member of the TNFR family, and DR4 induce FADD-dependent apoptosis and activate the NF-kappaB pathway. Immunity 1997, 7, 821-830. [CrossRef]

165. Wilson, N.S.; Dixit, V.; Ashkenazi, A. Death receptor signal transducers: Nodes of coordination in immune signaling networks. Nat. Immunol. 2009, 10, 348-355. [CrossRef]

166. Mitsiades, C.S.; Treon, S.P.; Mitsiades, N.; Shima, Y.; Richardson, P.; Schlossman, R.; Hideshima, T.; Anderson, K.C. TRAIL/Apo2L ligand selectively induces apoptosis and overcomes drug resistance in multiple myeloma: Therapeutic applications. Blood 2001, 98, 795-804. [CrossRef]

167. Ashkenazi, A.; Holland, P.; Eckhardt, S.G. Ligand-Based Targeting of Apoptosis in Cancer: The Potential of Recombinant Human Apoptosis Ligand 2/Tumor Necrosis Factor-Related Apoptosis-Inducing Ligand (rhApo2L/TRAIL). J. Clin. Oncol. 2008, 26, 3621-3630. [CrossRef]

168. Herbst, R.S.; Eckhardt, S.G.; Kurzrock, R.; Ebbinghaus, S.; O’Dwyer, P.J.; Gordon, M.S.; Novotny, W.; Goldwasser, M.A.; Tohnya, T.M.; Lum, B.L.; et al. Phase I dose-escalation study of recombinant human Apo2L/TRAIL, a dual proapoptotic receptor agonist, in patients with advanced cancer. J. Clin. Oncol. 2010, 28, 2839-2846. [CrossRef]

169. Pan, Y.; Xu, R.; Peach, M.; Huang, C.P.; Branstetter, D.; Novotny, W.; Herbst, R.S.; Eckhardt, S.G.; Holland, P.M. Evaluation of pharmacodynamic biomarkers in a Phase 1a trial of dulanermin (rhApo2L/TRAIL) in patients with advanced tumours. Br. J. Cancer 2011, 105, 1830-1838. [CrossRef]

170. Pitti, R.M.; Marsters, S.A.; Ruppert, S.; Donahue, C.J.; Moore, A.; Ashkenazi, A. Induction of apoptosis by Apo-2 ligand, a new member of the tumor necrosis factor cytokine family. J. Biol. Chem. 1996, 271, 12687-12690. [CrossRef]

171. Kay, B.P.; Hsu, C.P.; Lu, J.F.; Sun, Y.N.; Bai, S.; Xin, Y.; D’Argenio, D.Z. Intracellular-signaling tumor-regression modeling of the pro-apoptotic receptor agonists dulanermin and conatumumab. $J$. Pharmacokinet. Pharmacodyn. 2012, 39, 577-590. [CrossRef]

172. van der Sloot, A.M.; Tur, V.; Szegezdi, E.; Mullally, M.M.; Cool, R.H.; Samali, A.; Serrano, L.; Quax, W.J. Designed tumor necrosis factor-related apoptosis-inducing ligand variants initiating apoptosis exclusively via the DR5 receptor. Proc. Natl. Acad. Sci. USA 2006, 103, 8634-8639. [CrossRef] 
173. Bozic, I. Dynamics of Targeted Cancer Therapy. Trends Mol. Med. 2012, 18, 311-316. [CrossRef]

174. Yan, L.; Rosen, N.; Arteaga, C. Targeted cancer therapies. Chin. J. Cancer 2011, 30, 1-4. [CrossRef]

175. Viswanadha, V.P. An overview of targeted cancer therapy. BioMedicine 2015, 5, 1-6.

176. Lopez, J.S.; Banerji, U. Combine and conquer: Challenges for targeted therapy combinations in early phase trials. Nat. Rev. Clin. Oncol. 2017, 14, 57-66. [CrossRef]

177. Krause, D.S.; Van Etten, R.A. Tyrosine kinases as targets for cancer therapy. N. Engl. J. Med. 2005, 353, 172-187. [CrossRef]

178. Sangwan, V.; Park, M. Receptor tyrosine kinases: Role in cancer progression. Curr. Oncol. 2006, 13, $191-193$.

179. Manash, P.; Anup, M. Tyrosine kinase-Role and significance in Cancer. Int. J. Med. Sci. 2004, 1, 101-115.

180. Bose, P.; Gandhi, V.V.; Keating, M.J. Pharmacokinetic and pharmacodynamic evaluation of ibrutinib for the treatment of chronic lymphocytic leukemia: rationale for lower doses. Expert Opin. Drug Metab. Toxicol. 2016, 12, 1381-1392. [CrossRef]

181. Allocati, N.; Di Ilio, C.; De Laurenzi, V. P63/p73 in the control of cell cycle and cell death. Exp. Cell Res. 2012, 318, 1285-1290. [CrossRef]

182. Molina, J.R.; Adjei, A.A. The Ras/Raf/MAPK pathway. J. Thorac. Oncol. 2006, 1, 7-9. [CrossRef]

183. McCubrey, J.A.; Steelman, L.S.; Chappell, W.H.; Abrams, S.L.; Wong, E.W.T.; Chang, F.; Lehmann, B.; Terrian, D.M.; Milella, M.; Tafuri, A.; et al. Roles of the Raf/MEK/ERK pathway in cell growth, malignant transformation and drug resistance. Biochim. Biophys. Acta 2007, 1773, 1263-1284. [CrossRef]

184. Yu, Z.; Ye, S.; Hu, G.; Lv, M.; Tu, Z.; Zhou, K.; Li, Q. The RAF-MEK-ERK pathway: Targeting ERK to overcome obstacles to effective cancer therapy. Future Med. Chem. 2015, 7, 269-289. [CrossRef]

185. Muta, Y.; Matsuda, M.; Imajo, M. Divergent Dynamics and Functions of ERK MAP Kinase Signaling in Development, Homeostasis and Cancer: Lessons from Fluorescent Bioimaging. Cancers 2019, 11, 513. [CrossRef]

186. Lee, J.T.; Herlyn, M. MEK'ing the most of p53 reactivation therapy in melanoma. J. Invest. Dermatol. 2012, 132, 263-265. [CrossRef]

187. Davies, B.R.; Logie, A.; McKay, J.S.; Martin, P.; Steele, S.; Jenkins, R.; Cockerill, M.; Cartlidge, S.; Smith, P.D. AZD6244 (ARRY-142886), a potent inhibitor of mitogen-activated protein kinase/extracellular signal-regulated kinase kinase 1/2 kinases: Mechanism of action in vivo, pharmacokinetic/pharmacodynamic relationship, and potential for combination in preclinical. Mol. Cancer Ther. 2007, 6, 2209-2219. [CrossRef]

188. Porta, C.; Paglino, C.; Mosca, A. Targeting PI3K/Akt/mTOR Signaling in Cancer. Front. Oncol. 2014, 4, 1-11. [CrossRef]

189. Feng, Z.; Zhang, H.; Levine, A.J.; Jin, S. The coordinate regulation of the p53 and mTOR pathways in cells. Proc. Natl. Acad. Sci. USA 2005, 102, 8204-8209. [CrossRef]

190. Khan, K.H.; Yap, T.A.; Yan, L.; Cunningham, D. Targeting the PI3K-AKT-mTOR singnaling network in cancer. Chin. J. Cancer 2013, 32, 253-265. [CrossRef]

191. Richardson, P. Perifosine, an oral, anti-cancer agent and inhibitor of the Akt pathway: Mechanistic actions, pharmacodynamics, pharmacokinetics, and clinical activity. Expert Opin. Drug Metab. Toxicol. 2012, 8, 623-633. [CrossRef]

192. Sánchez-Martínez, C.; Gelbert, L.M.; Lallena, M.J.; De Dios, A. Cyclin dependent kinase (CDK) inhibitors as anticancer drugs. Bioorganic Med. Chem. Lett. 2015, 25, 3420-3435. [CrossRef]

193. Cicenas, J.; Kalyan, K.; Sorokinas, A.; Stankunas, E.; Levy, J.; Meskinyte, I.; Stankevicius, V.; Kaupinis, A.; Valius, M. Roscovitine in cancer and other diseases. Ann. Transl. Med. 2015, 3, 135.

194. Koivunen, J.; Aaltonen, V.; Peltonen, J. Protein kinase C (PKC) family in cancer progression. Cancer Lett. 2006, 235, 1-10. [CrossRef]

195. Cooke, M.; Magimaidas, A.; Casado-Medrano, V.; Kazanietz, M.G. Protein kinase C in cancer: The top five unanswered questions. Mol. Carcinog. 2017, 56, 1531-1542. [CrossRef]

196. Isakov, N. Protein kinase C (PKC) isoforms in cancer, tumor promotion and tumor suppression. Semin. Cancer Biol. 2018, 48, 36-52. [CrossRef]

197. Garg, R.; Benedetti, L.G.; Abera, M.B.; Wang, H.; Abba, M.; Kazanietz, M.G. Protein kinase C and cancer: What we know and what we do not. Oncogene 2014, 33, 5225-5237. [CrossRef]

198. Scott, A.M.; Allison, J.P.; Wolchok, J.D. Monoclonal antibodies in cancer therapy. Cancer Immun. 2012, 12, $1-8$. 
199. Chiavenna, S.M.; Jaworski, J.P.; Vendrell, A. State of the art in anti-cancer mAbs. J. Biomed. Sci. 2017, 24, 1-12. [CrossRef]

200. Nicodemus, C.F. Antibody-based immunotherapy of solid cancers: Progress and possibilities. Immunotherapy 2015, 7, 923-939. [CrossRef]

201. Cuesta-Mateos, C.; Alcaraz-Serna, A.; Somovilla-Crespo, B.; Muñoz-Calleja, C. Monoclonal antibody therapies for hematological malignancies: Not just lineage-specific targets. Front. Immunol. 2018, 8, 1936. [CrossRef]

202. New Clinical Trials of Monoclonal Antibodies Have Grown $115 \%$ in the Last Ten Years. Available online: https: / www.globaldata.com/new-clinical-trials-monoclonal-antibodies-grown-115-last-ten-years / (accessed on 18 July 2019).

203. Konstantinidou, M.; Zarganes-Tzitzikas, T.; Magiera-Mularz, K.; Holak, T.A.; Dömling, A. Immune Checkpoint PD-1/PD-L1: Is There Life Beyond Antibodies? Angew. Chem. Int. Ed. Engl. 2018, 57, 4840-4848. [CrossRef]

204. Freeman, C.L.; Sehn, L.H. A tale of two antibodies: Obinutuzumab versus rituximab. Br. J. Haematol. 2018, 182, 29-45. [CrossRef]

205. Gagez, A.-L.; Cartron, G. Obinutuzumab: A new class of anti-CD20 monoclonal antibody. Curr. Opin. Oncol. 2014, 26, 484-491. [CrossRef]

206. Owen, C.J.; Stewart, D.A. Obinutuzumab for the treatment of patients with previously untreated chronic lymphocytic leukemia: Overview and perspective. Ther. Adv. Hematol. 2015, 6, 161-170. [CrossRef]

207. Pirich, T.; Zwickl-Traxler, E.; Pecherstorfer, M.; Singer, J. Tolerability of obinutuzumab therapy in patients with rituximab-relapsed/refractory B-cell malignancies-A retrospective single center cohort study. Oncotarget 2018, 9, 29944-29956. [CrossRef]

208. Williams, R. Discontinued drugs in 2012: Oncology drugs. Expert Opin. Investig. Drugs 2013, 22, 1627-1644. [CrossRef]

209. Papandreou, C.N. The Proteasome as a Target for Cancer Treatment. Am. J. Cancer 2005, 4, 359-372. [CrossRef]

210. Richardson, P.G.; Mitsiades, C.; Hideshima, T.; Anderson, K.C. Proteasome inhibition in the treatment of cancer. Cell Cycle 2005, 4, 290-296. [CrossRef]

211. Orlowski, R.Z.; Kuhn, D.J. Proteasome inhibitors in cancer therapy: Lessons from the first decade. Clin. Cancer Res. 2008, 14, 1649-1657. [CrossRef]

212. Chen, D.; Frezza, M.; Schmitt, S.; Kanwar, J.; Dou, Q.P. Bortezomib as the first proteasome inhibitor anticancer drug: Current status and future perspectives. Curr. Cancer Drug Targets 2011, 11, $239-253$. [CrossRef]

213. Manal, M.; Chandrasekar, M.J.N.; Gomathi Priya, J.; Nanjan, M.J. Inhibitors of histone deacetylase as antitumor agents: A critical review. Bioorg. Chem. 2016, 67, 18-42. [CrossRef]

214. Brodie, S.; Brandes, J. Could valproic acid be an effective anticancer agent? The evidence so far. Expert Rev. Anticancer Ther. 2014, 14, 1097-1100. [CrossRef]

215. Kleeff, J.; Kornmann, M.; Sawhney, H.; Korc, M. Actinomycin D induces apoptosis and inhibits growth of pancreatic cancer cells. Int. J. Cancer 2000, 86, 399-407. [CrossRef]

216. Liu, X.F.; Xiang, L.; Zhou, Q.; Carralot, J.-P.; Prunotto, M.; Niederfellner, G.; Pastan, I. Actinomycin D enhances killing of cancer cells by immunotoxin RG7787 through activation of the extrinsic pathway of apoptosis. Proc. Natl. Acad. Sci. USA 2016, 113, 10666-10671. [CrossRef]

217. Bosschieter, J.; Nieuwenhuijzen, J.A.; van Ginkel, T.; Vis, A.N.; Witte, B.; Newling, D.; Beckers, G.M.A.; van Moorselaar, R.J.A. Value of an Immediate Intravesical Instillation of Mitomycin C in Patients with Non-muscle-invasive Bladder Cancer: A Prospective Multicentre Randomised Study in 2243 patients. Eur. Urol. 2018, 73, 226-232. [CrossRef]

218. Lu, D.; Wang, Y.; Li, C.; Wei, G.; Chen, R.; Dong, D.; Yao, M. Actinomycin D inhibits cell proliferations and promotes apoptosis in osteosarcoma cells. Int. J. Clin. Exp. Med. 2015, 8, 1904-1911.

219. Loh, S.N. The missing Zinc: P53 misfolding and cancer. Metallomics 2010, 2, 442-449. [CrossRef]

220. Morita, A.; Ariyasu, S.; Ohya, S.; Takahashi, I.; Wang, B.; Tanaka, K.; Uchida, T.; Okazaki, H.; Hanaya, K.; Enomoto, A.; et al. Evaluation of zinc (II) chelators for inhibiting p53-mediated apoptosis. Oncotarget 2013, 4, 2439-2450. [CrossRef] 
221. Kogan, S.; Carpizo, D.R. Zinc Metallochaperones as Mutant p53 Reactivators: A New Paradigm in Cancer Therapeutics. Cancers 2018, 10, 166. [CrossRef]

222. Adlard, P.A.; Bush, A.I. Metal chaperones: A holistic approach to the treatment of Alzheimer's disease. Front. psychiatry 2012, 3, 15. [CrossRef]

223. Lowe, S.W.; Ruley, H.E.; Jacks, T.; Housman, D.E. p53-dependent apoptosis modulates the cytotoxicity of anticancer agents. Cell 1993, 74, 957-967. [CrossRef]

224. Whitley, D.; Goldberg, S.P.; Jordan, W.D. Heat shock proteins: A review of the molecular chaperones. J. Vasc. Surg. 1999, 29, 748-751. [CrossRef]

225. Schneider, C.; Sepp-Lorenzino, L.; Nimmesgern, E.; Ouerfelli, O.; Danishefsky, S.; Rosen, N.; Hartl, F.U. Pharmacologic shifting of a balance between protein refolding and degradation mediated by Hsp90. Proc. Natl. Acad. Sci. USA 1996, 93, 14536-14541. [CrossRef]

226. Flandrin, P.; Guyotat, D.; Duval, A.; Cornillon, J.; Tavernier, E.; Nadal, N.; Campos, L. Significance of heat-shock protein (HSP) 90 expression in acute myeloid leukemia cells. Cell Stress Chaperones 2008, 13, 357-364. [CrossRef]

227. Wiedmann, R.M.; von Schwarzenberg, K.; Palamidessi, A.; Schreiner, L.; Kubisch, R.; Liebl, J.; Schempp, C.; Trauner, D.; Vereb, G.; Zahler, S.; et al. The V-ATPase-inhibitor archazolid abrogates tumor metastasis via inhibition of endocytic activation of the Rho-GTPase Rac1. Cancer Res. 2012, 72, 5976-5987. [CrossRef]

228. Schempp, C.M.; von Schwarzenberg, K.; Schreiner, L.; Kubisch, R.; Muller, R.; Wagner, E.; Vollmar, A.M. V-ATPase Inhibition Regulates Anoikis Resistance and Metastasis of Cancer Cells. Mol. Cancer Ther. 2014, 13, 926-937. [CrossRef]

229. Bartel, K.; Winzi, M.; Ulrich, M.; Koeberle, A.; Menche, D.; Werz, O.; Müller, R.; Guck, J.; Vollmar, A.M.; von Schwarzenberg, K. V-ATPase inhibition increases cancer cell stiffness and blocks membrane related Ras signaling-A new option for HCC therapy. Oncotarget 2017, 8, 9476-9487. [CrossRef]

230. Kasper, E.; Angot, E.; Colasse, E.; Nicol, L.; Sabourin, J.C.; Adriouch, S.; Lacoume, Y.; Charbonnier, C.; Raad, S.; Frebourg, T.; et al. Contribution of genotoxic anticancer treatments to the development of multiple primary tumours in the context of germline TP53 mutations. Eur. J. Cancer 2018, 101, 254-262. [CrossRef]

231. Zi, F.; Zi, H.; Li, Y.; He, J.; Shi, Q.; Cai, Z. Metformin and cancer: An existing drug for cancer prevention and therapy (review). Oncol. Lett. 2018, 15, 683-690. [CrossRef]

232. Franciosi, M.; Lucisano, G.; Lapice, E.; Strippoli, G.F.M.; Pellegrini, F.; Nicolucci, A. Metformin Therapy and Risk of Cancer in Patients with Type 2 Diabetes: Systematic Review. PLoS ONE 2013, 8, 1-12. [CrossRef]

233. Lane, D.P.; Cheok, C.F.; Lain, S. P53-Based Cancer Therapy. Cold Spring Harb. Perspect. Biol. 2010, 2, 1-24. [CrossRef] [PubMed] 